\title{
K

\section{Analogías impertinentes. Voces, canciones y artefactos tecnológicos en la revisión de los setenta del cine argentino reciente}

Impertinent analogies. Voices, songs and technological artefacts in the revision of the 1970 s in recent Argentine cinema

\section{SOPHIE DUFAYS / PABLO PIEDRAS \\ KU Leuven (Bélgica) / CONICET-UBA (Argentina)}

sophie.dufays@uclouvain.be / https://orcid.org/0000-0001-8867-922X

Recibido: 3 de noviembre de 2020

Aceptado: 22 de febrero de 2021 pablo.piedras@yahoo.com.ar / http://orcid.org/0000-0002-3525-0507 https://doi.org/10.7203/KAM.17.17558 N. 17 (2021): . ISSN: 2340-1869
RESUMEN: Este artículo propone un análisis comparado de dos películas argentinas de 2017 que revisan los primeros años setenta (o sea, los años previos al golpe cívico-militar de 1976) de un modo que nos parece sintomático de sus circunstancias políticas, culturales y cinematográficas: Sinfonía para Ana (Ernesto Ardito y Virna Molina) y Desearás al hombre de tu hermana (Diego Kaplan). Más allá de sus diferencias evidentes -las que distingue un cine de autor de un cine comercial de estética publicitaria-, ambas obras basan su reconstrucción afectiva de los setenta en el papel de la voz grabada y de algunas canciones populares de la época. Después de una introducción contextual, concentramos nuestro análisis en estos dos componentes, vinculándolos con la puesta en escena de las miradas (de deseo o de control) y del espacio (marcadamente clausurado), para mostrar cómo desde esas instancias se anudan sensualidad y violencia en las nuevas versiones mnemónicas de los setenta que ofrecen ciertos films argentinos recientes. Al mismo tiempo, subrayamos la (tec)nostalgia asociada a la presencia insistente de aparatos analógicos de grabación y reproducción en los planos fímicos, señalando cómo dichos objetos contribuyen a auratizar esa época predigital, reconstruyéndola como un tiempo "caliente" de la historia.

PALABRAS CLAVE: cine argentino, revisión de los 1970 , memoria cultural, perspectiva culturalista, canciones en el cine, canciones populares, nostalgia, tecnología analógica.
ABSTRACT: This paper offers a comparison between two Argentine films of 2017 that revisit the first seventies (that is, the years previous to the civic military coup) in a way that we find symptomatic of their political, cultural and cinematographic context: Sinfonía para Ana (Symphony for Ana, Ernesto Ardito y Virna Molina) y Desearás al hombre de tu hermana (Desire, Diego Kaplan). Beyond their obvious differences - the differences between an independent author's film and a commercial one-, both films base their affective reconstruction of the seventies on the role of recorded voices and of some popular songs from that time. After a contextual introduction, we focus our analysis on these two components (voices and songs), connecting them with the mise-en-scène of the gaze (a gaze of desire or control) and the space (a markedly closed space) in order to show how, from these elements, sensuality and violence are tied in the new mnemonic versions of the seventies that these films offer. At the same time, we highlight the (tech)nostalgia associated with the visual recurrence of analog recording and reproduction devices, pointing out how such objects contribute to auratize that predigital era, projecting it as a "hot" time in history.

KEYWORDS:Argentine cinema, revision of the 1970s, cultural memory, culturalist perspective, songs in cinema, popular songs, nostalgia, analog technology. 


\section{INTRODUCCIÓN: LA RECUPERACIÓN AFECTIVA DE LOS SETENTA EN EL CINE ARGENTINO CONTEMPORÁNEO}

En sus revisiones del pasado reciente, el cine de la recuperación democrática transitó con asiduidad la década de los setenta. Los años referidos a la dictadura militar, al accionar represivo y terrorista del Estado y a sus secuelas en el tejido social de los primeros ochenta fueron los tópicos cuya representación organizó una zona de la cinematografía del período. La alianza entre el cine de autor y el cine comercial, impulsada por la política de fomento del Instituto Nacional de Cine (INC, dirigido por Manuel Antín desde 1983$)^{\mathrm{I}}$, ya fuese en su vertiente genérica - el melodrama en La historia oficial (Luis Puenzo, I985) - o en su vertiente testimonial - La noche de los lápices (Héctor Olivera, I986) - apeló a la historia reciente para activar la memoria afectiva de las audiencias, en sintonía con las políticas de derechos humanos y con los usos del pasado del gobierno radical $^{2}$.

En el marco de la profunda crisis del cine nacional registrada hacia mediados de los noventa, una serie de documentales sobre los años setenta se diferenció de los films anteriormente mencionados. Surgieron así testimonios de militantes de la izquierda peronista, especialmente, aunque no solo, de Montoneros en Cazadores de utopías (David Blaustein, 1995) y Montoneros, una historia (Andrés Di Tella, I994-I998). Estos visibilizaron y reivindicaron formas de actividad política que el cine precedente tendió a minimizar para favorecer la figura de las víctimas de la dictadura militar y abonar el discurso de los derechos humanos 3 .

En el siglo XXI, junto con una fuerte producción de documentales performativos, realizados por hijos de militantes asesinados o desaparecidos - Los rubios (Albertina Carri, 2003), $M$ (Nicolás Prividera, 2006) ${ }^{4}$ - se percibe un renovado impulso por representar la década de los setenta en producciones que, en cierto sentido, exhuman la alianza entre cine de autor y cine comercial de la redemocratización, con el objeto de pensar los setenta "de otra manera" o de recuperar los setenta "de la gente común", parafraseando los títulos de los influyentes libros de Isabella Cosse, Karina Felitti y Valeria Manzano (2010) y de Sebastián Carassai (2013). A través de narrativas que dialogan con los géneros cinematográficos - El secreto de sus ojos (Juan José Campanella, 2009), La mirada invisi-

I Sobre las políticas instauradas por el INC bajo la presidencia de Manuel Antín, véase Lusnich (I994).

2 Remitimos al trabajo de Lucía Brienza (20I0), quien examina los usos del pasado reciente que hizo el gobierno radical de Raúl Alfonsín para sustentar el debate y las políticas públicas de aquel tiempo.

3 Javier Campo (20I8), a partir de nociones de Emilio Crenzel, ha estudiado la apropiación en el cine argentino documental de las décadas de los setenta y ochenta de las narrativas revolucionarias y de las democrático-humanitarias.

4 Entre la profusa bibliografía sobre la temática, véanse Gonzalo Aguilar (2006), Laia Quílez Esteve (2008), Ana Amado (2009) y Pablo Piedras (2014). 
ble (Diego Lerman, 20I0), Infancia clandestina (Benjamín Avila, 201I), Desearás al hombre de tu hermana (Diego Kaplan, 20I7), Rojo (Benjamín Naishtat, 2018)-, mediante el concurso de figuras de la crónica roja - El clan (Pablo Trapero, 2015) y El ángel (Luis Ortega, 20I8) - , o desde una perspectiva que observa la vida cotidiana de la clase media $-L a$ larga noche de Francisco Sanctis (Andrea Testa y Francisco Márquez, 2016), Sinfonía para Ana (Ernesto Ardito y Virna Molina, 20I7) - , pareciese existir un empeño del cine argentino contemporáneo en examinar los setenta con un prisma más interesado en capturar las circunstancias culturales (familiares, afectivas, domésticas, sexuales) que fundaron la "época" (Gilman, 2003), que en restituir las coyunturas políticas (públicas, históricas, gubernamentales) que la signaron.

La violencia es un elemento omnipresente en los films señalados, aunque no se presenta preponderantemente a partir del accionar de las fuerzas represivas del Estado. Existen, en cambio, figuraciones de la violencia en tanto fantasma que amenaza, coacciona y se ciñe sobre el destino de los personajes; expresiones de ultraje e intimidación sexual y de género; formas simbólicas de la opresión; y también, claro, violencia física y directa sobre los cuerpos pero que no está monopolizada por los aparatos de gobierno.

El sustrato violento es entonces un denominador común en las películas argentinas contemporáneas que remontan su diégesis a la década de los setenta. Tras esta afirmación que parte de la observación del material fílmico, nuestro artículo intentará responder las siguientes preguntas: ‘a qué se debe este nuevo retorno de los setenta en el cine de ficción nacional? ¿A qué corresponde el desplazamiento de las representaciones de la violencia desde el espacio público y político hacia el espacio doméstico y cultural? ¿A qué estrategias discursivas recurren las obras para componer las atmósferas afectivas y experienciales de la década de los setenta en contraposición con las películas producidas en otros momentos históricos?

Adelantaremos tres hipótesis, tras las cuales desarrollaremos el análisis y la argumentación de nuestro ensayo. En primer lugar, el campo cultural argentino, con el arribo de Néstor Kirchner al poder, en el año 2003, mostró un creciente interés en los debates sobre la violencia política de los setenta, respecto de la actuación de las agrupaciones armadas y, sobre todo, el despliegue de intensas políticas de justicia, verdad y memoria gracias a la reactivación de los juicios por crímenes de lesa humanidad. La convalidación de la Corte Suprema de Justicia, en el año 2005, de la derogación de las leyes de Punto final y Obediencia debida resultó un espaldarazo simbólico y legal fundamentals. En este contexto, la reivindicación de los organismos de derechos humanos, convertida en política de Estado,

5 La anulación de las dos leyes de impunidad se concretó en el Senado de la Nación el 2I de agosto de 2003. Ambas leyes habían sido propugnadas durante el gobierno radical en los años i986 (Punto final) y I987 (Obediencia debida). 
efectuada por los gobiernos kirchneristas y una serie de políticas públicas de memoria ubicaron en el centro de la escena a los años setenta ${ }^{6}$. Los efectos de este fenómeno reverberaron, de múltiples modos, en los medios de comunicación, en los ámbitos académicos-intelectuales e, indisociablemente, en los espacios artísticos. En segundo lugar, esta nueva revisión de los años setenta se articuló, en los campos cultural e intelectual, con un actualizado interés de los historiadores, periodistas, sociólogos y, también, de los artistas, por el hacer de la historia cultural y de la microhistoria7. Así, el modo de mirar nuevamente la época requirió de una luz focalizada en zonas más acotadas del pasado y en perspectivas que pudiesen recobrar la experiencia cotidiana y los imaginarios sociales de quienes vivieron aquellos años, y no necesariamente se involucraron en la cosa pública y en la arena política. En tercer lugar, consideramos que en el cine argentino de los últimos años se visualiza una consolidación de la ficción comercial con caracteres autorales. Un sector de esta producción ha dotado a la figuración de los años setenta de una nueva atmósfera que se formula a partir de una renovada atención sobre los dispositivos y las formas de reproducción de sonido como objeto nodal de la puesta en escena. En este marco, las canciones populares, particularmente el repertorio melódico de la llamada "música ligera" del período ha contribuido a recrear los contornos culturales, las experiencias afectivas y la composición del lazo social (relaciones de poder, pujas de género, identidades sexuales, disputas al interior de la familia), sobre todo en las clases medias.

Para ahondar en estas ideas efectuaremos un análisis comparativo de dos películas ambientadas en los años setenta estrenadas en 20I7: Sinfonía para Ana (Ernesto Ardito y Virna Molina) y Desearás al hombre de tu hermana (Diego Kaplan). El riesgo que asume la propuesta — asentado en las distancias de escala de producción, de temáticas, de estilos de puesta en escena y de actuación, de sistema de estrellas (o la inexistencia de este), del modelo de audiencia al que se orientan las obras ${ }^{8}$ - más allá de plantear una provocación metodológica e ideológica, está justificado en la vocación historiográfica y en la propuesta analítica del artículo. Sintéticamente, si damos por válida la existencia de una

6 Estos debates y una serie de circunstancias políticas contemporáneas como el fallo de la Corte Suprema que habilitaba el 2 x I para procesados por delitos de lesa humanidad (2017) -rectificado ante la movilización social- son el tema del libro de Claudia Hilb, ¿Por qué no pasan los 70 ? No hay verdades sencillas para pasados complejos (2018).

7 Para comprender las transformaciones de la historia cultural en nuestro país, véase el artículo de Lila Caimari (2007). Marina Franco y Daniel Lvovich (2017) trazan un panorama acorde con nuestro punto de vista respecto de cómo se han reconfigurado las perspectivas de la historia reciente y de los estudios sobre memoria en los últimos años.

8 Sinfonía para Ana hizo un recorrido por festivales internacionales de cine durante los años 2017 y 2018 y permaneció durante varios meses en las carteleras de la Argentina, sobre todo gracias a la publicidad fruto de la recomendación "boca a boca" de los espectadores. Desearás al hombre de tu hermana tuvo una vida abreviada en las carteleras de cine comercial en Argentina pero encontró su público en Netflix, donde resultó exitosa. 
tendencia culturalista en la recuperación de los setenta en el cine argentino reciente, entonces el criterio de selección de los films nos permite examinar los dos extremos de un arco compuesto por un corpus fílmico heterogéneo. Sinfonía... es una producción más cercana al cine independiente - aunque cuenta con el apoyo del INCAA- sobre la militancia de la UES (Unión de Estudiantes Secundarios) en el Colegio Nacional de Buenos Aires, anclada en la antesala y el inicio del golpe de Estado de 1976. Desearás... es un film que bascula entre una estética que podemos calificar como kitsch y el erotismo para valijeros, organizado para el lucimiento de la modelo mediática Carolina "Pampita" Ardohaín. Sinfonía... es la primera incursión de peso en la ficción de dos directores provenientes del documental político. Desearás... es el cuarto largometraje de un director formado en la factoría de Adrián Suar.

No obstante, las dos obras comparten la intención de realizar una reconstrucción afectiva y sonora de los setenta, la relevancia de la voz grabada y el peso de algunas canciones populares de la época. También tienen en común una acción dramática concentrada primordialmente en un espacio cerrado -el colegio (Sinfonía...), la casa (Desearás...) - y el protagonismo de mujeres a la hora de narrar la realidad que las circunda. No es casual que la guionista y autora de la novela original en la que se basa Desearás al hombre de tu hermana, Erika Halvorsen, justifique la ambientación en los setenta desde un ángulo de género por recuperar la vivencia de las mujeres en esta época:

contamos la relación de estas mujeres que nos precedieron [...] Son nuestras madres, nuestras abuelas, y si bien en este caso son mujeres muy conectadas con su sexualidad, también son mujeres que quedaban atrapadas en el deseo del hombre. [...] es un poco realizarnos como mujeres mirando para atrás las generaciones que nos precedieron. (en Ortiz, I6/10/2017)

En las dos películas, pero también en las otras que hemos mencionado, reconocemos algo que Karin Bijsterveld y José van Dijck destacan en su libro Sound Souvenirs. Audio Technologies, Memory and Cultural Practices: "la importancia del sonido para los actos de recordación y para la creación de sentidos de pertenencia"9(2009: II). Asimismo, estas obras sintonizan con el enfoque académico que ha emergido en la última década a partir del cruce entre los estudios sobre memoria (memory studies) y los estudios sobre medios (media studies), el cual insiste en el papel de las tecnologías de sonido en prácticas memoriales personales y colectivas "las personas hacen uso de las tecnologías de sonido para traer al presente, reconstruir, celebrar y gestionar sus memorias, o incluso un pasado, de los cuales ellas no fueron partícipes" (Ídem). En los films sobre los setenta, la valencia de la puesta en escena de aparatos analógicos de grabación y reproducción

9 Todas las traducciones pertenecen a los autores del ensayo. 
se articula con un énfasis especial en la inclusión de canciones melódicas y de rock de alcance masivo de la época, en tanto objetos mnemónicos singulares que epitoman una atmósfera afectiva y un tipo de consumo sentimental propios de la cultura popular.

\section{EL CASETE Y LA VOZ GRABADA}

La trama de estas dos películas que recrean el ambiente afectivo de los setenta se estructura en torno a un relato grabado por las protagonistas en una cinta magnética, al que otro(s) personaje(s) escucha(n). En ambos casos se trata de un relato a la vez iniciático e íntimo, pero en Desearás... toma la forma de un diario en el que Ofelia comenta para sí misma su iniciación sexual, mientras que en Sinfonía... se presenta como un testimonio que Ana dirige a su amiga Isa y donde narra su descubrimiento del amor y de la militancia política, dos aspectos inseparables en su experiencia ${ }^{\mathrm{I}}$.

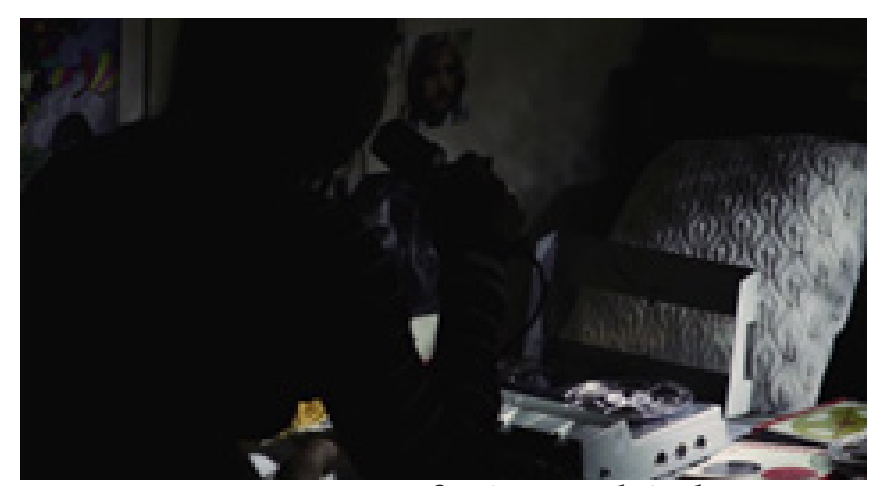

Figura I: Ana (Sinfonía...) grabándose

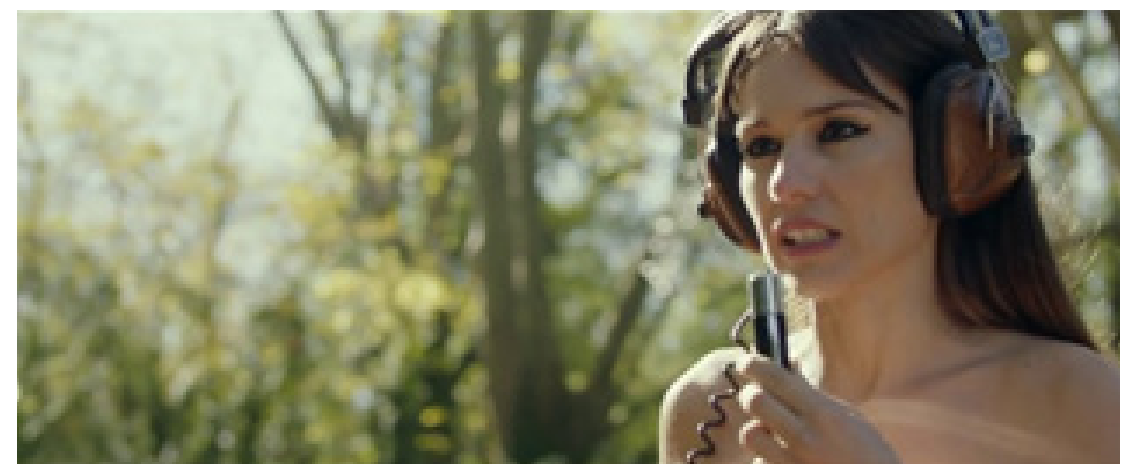

Figura 2: Ofelia (Desearás...) grabándose

Io Nora Catelli sostiene que el diario íntimo de mujer - narrativa que, con sus matices, resulta central en los dos films - podría ser considerado "el lugar de escritura más cercano a la verdad existencial de lo diferente" (2007: 45). Esta idea nos permite comprender que la inscripción de la historia en estas obras está dotada de una cierta lateralidad, instaurada por el propio lugar de enunciación de estas voces femeninas, que revisan la época desde un prisma no hegemónico. Asimismo, los significantes "diario" y "Ana" remiten a una obra fundamental de la literatura del siglo XX: El diario de Ana Frank, 1947. En dicho relato una adolescente llamada Ana, muerta en un campo de concentración, narra a una amiga imaginaria la historia de su padecimiento durante el nazismo. 
El gesto de desobediencia a la autoridad de la protagonista de Sinfonía... es doble: hacia los padres, en la esfera doméstica; hacia el poder político hegemónico, en la esfera pública. El relato grabado y reproducido en el desarrollo del film recupera las facetas de lo íntimo: incide psíquica, política y moralmente en la narración de su propia historia hacia otro sujeto (su amiga) y es, a la vez, la demostración de una amistad que ha trascendido el tiempo y la historia. Las grabaciones de Ofelia en Desearás... penetran en la vida íntima de su hermana (a través de la escucha compulsiva de su novel marido, Juan), y asimismo presentan de modo invertido el que había sido el relato dominante de la familia sobre la historia amorosa de las dos hermanas.

En ambos films la voz de una adolescente surge desde el prólogo, pero el papel estructurador y la relación con los objetos tecnológicos que permiten su escucha (las cintas y los grabadores de carrete abierto portátiles) se despliegan de modos distintos. En lo que sigue, abordaremos los valores que se otorgan a la voz y a la tecnología en cada película, proponiendo que estos dos factores articulan el espesor temporal de las narraciones.

\section{TODO SOBRE ANA}

Sinfonía para Ana empieza con el sonido de una grabadora que se pone en marcha y la voz de Ana, antes de cualquier imagen: la voz en off grabada de la protagonista es la que guía la trama narrativa y la que "da a ver" las imágenes ${ }^{\text {II }}$ las cuales se presentan como "imágenes-recuerdo", productos de una memoria íntima, pero socialmente compartida debido a los acontecimientos históricos que son restituidos en el relato. Las primeras imágenes muestran la cinta magnética que Ana utiliza para grabarse. Visualmente, la bobina girando sustituye al cuerpo o a la boca del personaje, cobrando asimismo un estatuto fantasmal (ese objeto es lo que queda de ella después de su desaparición) que se suma al valor documental reivindicado discursivamente: "Hola Isa. Soy Ana. Ya pasaron dos semanas del golpe y no aguanto más. Necesito hablarte. Por eso te grabo esta cinta. Mis viejos no tienen que enterarse. O la van a quemar. Por miedo". La cinta se presenta entonces como un archivo testimonial que responde a la urgencia de hablar; un archivo amenazado - no solo por la situación política, sino por su propia naturaleza analógica-, que requiere cuidado y protección por parte de su público. Ilustrando el discurso de la voz, una serie de planos muestra documentos que se están quemando. Se trata de archivos tan colectivos como personales: una hoja de apuntes de una clase, la primera plana del diario El Descamisado, el libro La lucha por la liberación nacional (i960) de John William Cooke, una foto de Ana e Isa. Esta mezcla de documentos privados y públicos

II Solo el final - su muerte- será contado por la voz de Isa, figura delegada del espectador a la que el relato anterior se dirigía. 
anuncia la propuesta fundamental de la película que, para evocar los años 1973-1976, integra constantemente en los planos de la historia ficticia de Ana una miríada de archivos históricos de la época (voces de radio, diarios, imágenes televisuales, fotos, etcétera), construyendo un collage de imágenes heterogéneas que encuentra su cohesión gracias a la "atmósfera sonora" sostenida por la voz grabada de Ana ${ }^{\mathrm{r}}$.
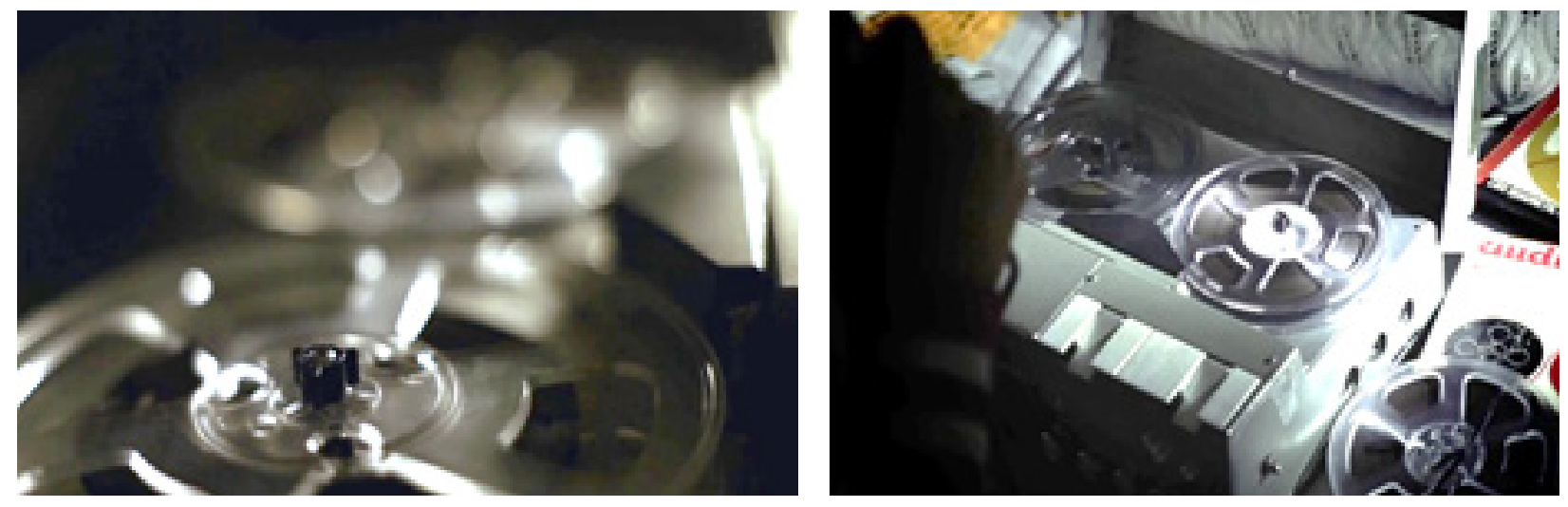

Figuras 3 y 4: fotogramas del íncipit de Sinfonía para Ana (2017)

La película sugiere asimismo que esta inseparabilidad de los registros político e íntimo hunde sus raíces en aquellos tiempos de democracia frágil. Si bien el relato de Sinfonía para Ana se inicia en los años previos al golpe y muestra el momento anterior a la desilusión de la juventud peronista después del retorno de Perón al poder en I973, concentra su acción y su conflicto dramático en el oscuro período que media entre la muerte del líder ( $\mathrm{I}^{\circ}$ de julio de 1974) y el golpe de Estado del 24 de marzo de I976. Se trata de una etapa de profunda inestabilidad política y económica, pero, sobre todo, de desencanto generacional ante el giro acelerado del tercer gobierno de Juan Domingo Perón hacia la derecha, cuyo exponente más violento fueron las operaciones de la organización terrorista paraestatal Triple A (Alianza Anticomunista Argentina). No es casual que la acción de Rojo y El secreto de sus ojos esté situada en esos mismos años porque en ellos se puede ver, como en un tubo de ensayo, algunos de los rasgos de la violencia política que se radicalizaría y sistematizaría con la dictadura militar.

I2 Ernesto Ardito comenta su film con esos mismos términos: "La época se da como un collage. Hay un entramado de diferentes recursos cinematográficos que van generando esa época: trucos de fotos, archivo, rodaje directo, tomas sensoriales. Por eso es muy importante el trabajo que estamos haciendo con la atmósfera sonora: la época va ingresando a través de las radios, los discursos políticos y la televisión" (en Bilik, 20I6: 76, subrayado nuestro). Vale recordar que la ópera prima de Virna Molina y Ernesto Ardito, Raymundo (2002), organizaba su entramado narrativo, de orden documental, mediante las voces de los protagonistas y un ensamblado de materiales de archivo heterogéneo tratados con técnicas digitales de montaje que los dotaba de dinamismo y fluidez. Si en aquella película algunas estrategias habituales de la ficción (la intriga de predestinación, por ejemplo) modulaban un relato documental, en esta, los materiales de archivo, que habitualmente hacen parte de la narrativa documental, son semantizados por un relato ficcional. 
La voz de Ana es el hilo conductor que sirve para articular imágenes de distinto origen. Por un lado, dota las imágenes de archivo de un valor afectivo íntimo y, por otro, da un estatuto mnemónico y hasta documental a los rostros adolescentes, objetos principales de los planos ficcionales. La opción estética-narrativa de concentrarse en los rostros de los personajes, el film la asume explícitamente desde una cita cinéfila de $L a$ pasión de Juana de Arco de Carl T. Dreyer (1928) - película conocida por ser rodada casi exclusivamente con primeros planos- y además se justifica desde una declaración de Ana, con la que concluyen los créditos: "Me desespera cuando se me borra un rostro. Un momento. Un gesto. Porque es como matarlos". A partir de allí, la voz de Ana vincula los documentos (que corren el riesgo de desaparecer de la historia) con los rostros que pueden "borrarse" de la memoria ${ }^{13}$. De modo significativo, el aparato sonoro que contiene esta voz, la grabadora, se asocia visualmente con los otros aparatos de grabación o de reproducción analógica que aparecen en la película: el tocadiscos del cuarto de Lito (lo cual vincula la voz de Ana con las canciones de rock de los vinilos) y la cámara analógica super- 8 de marca Elmo que posee el padre de Isa. El correr de la cinta en el magnetófono de bobina abierta alude también, claramente, al rollo que gira en el proyector cinematográfico. Si bien este último aparato permanece invisible en Sinfonía..., su presencia física se siente en las secuencias en las que Ana e Isa miran juntas películas militantes en el microcine del colegio o filmaciones en super-8 de su infancia: en esas secuencias se resaltan el ruido y el parpadeo del proyector. Después del breve prólogo, los planos con los créditos iniciales se intercalan con imágenes en super- 8 de las dos amigas en torno a un árbol de Navidad. Estas imágenes se caracterizan por ese similar carácter tembloroso y borroso, que produce un doble efecto de autenticidad y de fragilidad. Se puede decir que la voz grabada en el magnetófono encuentra su equivalente visual en el uso recurrente de filmaciones en super-8 de los personajes ficcionales. Dicha estrategia visual denota el deseo de los directores de evocar los años setenta desde el formato mismo de las imágenes y desde una práctica mnemónica familiar y popular de esa época ${ }^{14}$, más aun, que (o

I3 María Belén Lo Russo y María Florencia Lo Russo (2018) estudian el film de Molina y Ardito desde la perspectiva de la cultura de la memoria y remiten también a ciertas conexiones (no solo iconográficas) entre Sinfonía para Ana y el film de Carl. T. Dreyer. Aunque coincidimos con estas afinidades, también creemos que debe interpretarse esta elección de orden visual en el marco general de las condiciones de producción y de la política estética del film. La escasez de profundidad de campo y la abundancia de planos detalle y de primeros planos se amalgaman en una estética del fragmento (y de la epidermis, por la precisión con que se distinguen los poros de la piel) - que hace serie con la incorporación de materiales de archivo en el montaje- apoyada en un diseño de producción que no precisa de mayores reconstrucciones escenográficas y objetos de utilería de época.

I4 En efecto, esa cámara amateur se vinculaba con la práctica mnemónica de rodar films de familia. Patricia Zimmermann (I995) efectuó un estudio fundamental sobre el aporte de las "películas domésticas" (family reels, home-movies) en tanto materiales subvalorados para la construcción de una historia social del siglo XX. Asimismo, la autora observa con atención el reciclaje de películas familiares realizado por 
al menos tanto como) por lo que representa ${ }^{15}$.
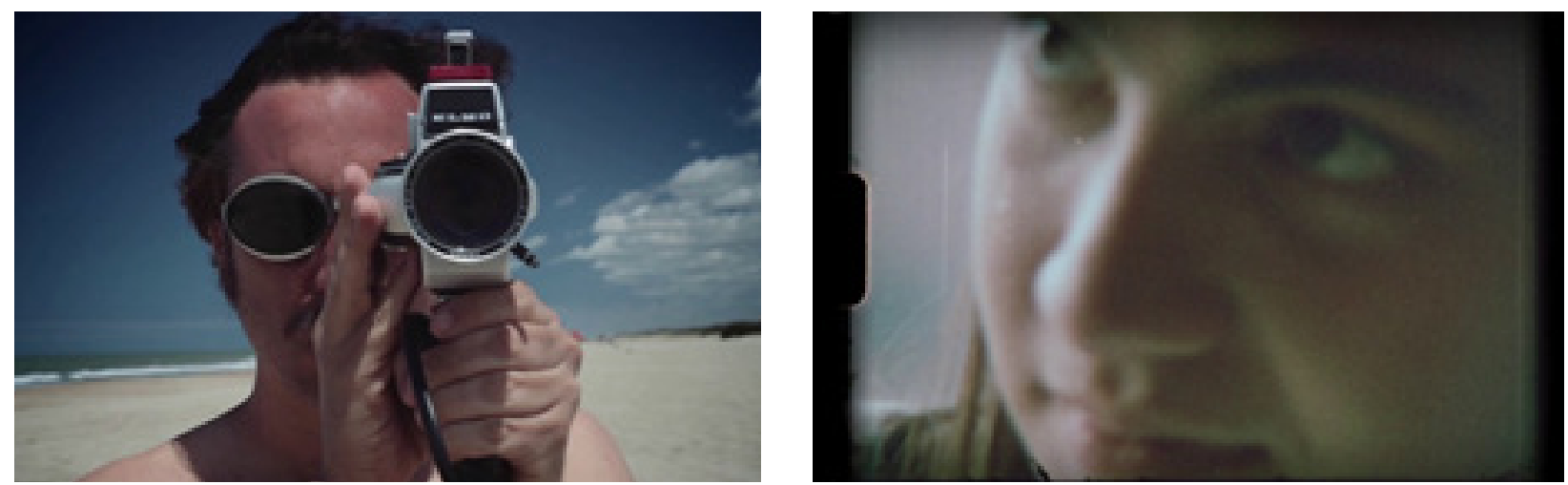

Figuras 5 y 6: cámara super-8 del padre de Isa e imagen de Ana en super-8 (Sinfonía...)

A nivel sonoro, se superponen el ruido del proyector y una voz femenina tarareando en eco la suave melodía de lo que podría ser una canción de cuna, que refiere a un tiempo lejano y feliz. El eco remite a la imperfección del aparato y del proceso de grabación. Esta construcción audiovisual anclada en dos máquinas de tecnología analógica (proyector de cine y magnetófono) se asocia a la percepción inestable de un niño (destinatario de la melodía), como si la época retratada constituyera la infancia del tiempo presente en el que se rodó el film (20I7).

Es interesante la asociación que se plantea aquí entre una percepción infantil y la tecnología analógica: ambas sirven para privilegiar la materialidad sensorial del sonido, más allá del posible discurso verbal que entrega. Asimismo, las dos suscitan nostalgia: la nostalgia de Ana por su propio pasado y la de los espectadores de 2017 por los valores colectivos que se proyectan en él (compromiso, solidaridad, resistencia, autenticidad e intensidad de las relaciones y de las emociones) se refuerzan y a la vez se vuelven más reflexivas al transmitirse desde la mediación de unos dispositivos tecnológicos que susci-

videoclips y el modo en que los comerciales miman este tipo de films con el objeto de crear (y de vender) un espectáculo de autenticidad e intimidad.

I5 Es llamativo que las estrategias por emular las texturas y los formatos fílmicos de la década de los setenta sean un denominador común en el conjunto de películas que hemos citado. Esta cualidad diferencia el corpus fílmico contemporáneo sobre los setenta de otras obras producidas en décadas anteriores. Entre los tantos ejemplos pueden citarse la saturación cromática en Rojo, Desearás... y El ángel; el uso del ralentí en Rojo, Desearás..., El clan y El ángel; la inclusión de imágenes en blanco y negro que simulan archivos televisivos de la época en El ángel (la presentación de Palito y Marisol en la Televisión Española) y en El secreto de sus ojos (la aparición del asesino como guardaespaldas de María Estela Martínez de Perón en un noticiero falseado). Habría que revisar hasta qué punto esta no es una tendencia más general en el uso de la tecnología digital que se da en la contemporaneidad con el fin de "reauratizar" las imágenes que han perdido su carácter "químico-fotográfico", esto es, su relación físico-indicial con la realidad. Los celulares, los programas informáticos de edición, las cámaras digitales brindan una nutrida gama de filtros que hacen lucir lo registrado como si fuese sepia, blanco y negro, con manchas de desgaste fílmico, con textura de super-8 y un largo etcétera de visualidades "vintage". 
tan una "tecnostalgia" típica de la era digital contemporánea ${ }^{16}$. En efecto, como ha analizado Tim van der Heijden, "en las prácticas contemporáneas de memoria las tecnologías de comunicación no solo construyen y median las memorias, sino que se han convertido ellas mismas en objetos de memoria" (2015: 104). Además de la grabadora y de la cámara super-8, el film dedica numerosos primeros planos a los objetos que representan los medios de comunicación de la broadcast era predigital: televisión, radio, teléfono, cámara fotográfica, diapositivas, máquina de escribir. Esos múltiples objetos tecnológicos recurrentemente filmados al lado de los rostros adolescentes no sirven solo como vehículos de las voces e imágenes del pasado, sino que encarnan la percepción de ese pasado, una percepción que se da como "analógica" (con una confusión entre lo analógico y lo indi(ial) $)^{17}$, o sea, que pretende reproducir la sensación y la "textura", el "grano" de lo que fue ${ }^{\mathrm{I} 8}$.

En una entrevista, los directores del film han expresado su propia nostalgia por el "misterio" que proporcionaba la imagen analógica y el deseo de emular su efecto. Para Virna Molina "el soporte [...] aporta la textura. Me hubiera gustado hacerla [la película] en fílmico. [...] Hoy, casi el único formato posible es el digital, y eso te marca. No me gusta esa imagen tan nítida, donde se ve todo sin misterio" (en Bilik, 2016: 76); y Ardito completa: "trabajamos en digital pero con lentes de los 70'. Eso le da otra textura a la imagen" (Ídem). Desde esta perspectiva, es significativo que en vez de filmar directamente en digital aplicando un filtro retro, prefirieran rodar algunas secuencias con una cámara super-8 y luego escanearlas fotograma por fotograma en $4 \mathrm{k}$ (Ídem): este proceso más trabajoso manifiesta el afán por recuperar desde lo digital el aura misteriosa que, según ellos, transmitían los soportes analógicos.

I6 Más allá de cierto carácter global que le asignamos a la tecnostalgia, el discurso histórico-político de Sinfonía para Ana, a través de las estrategias de actualización descriptas, resuena en un presente de recepción localizado e intensamente marcado por la coyuntura política argentina. En este sentido el film también debe ser interpretado como un acto militante frente a las políticas de desmemoria y borramiento del pasado impulsadas por el gobierno neoliberal, conservador y negacionista del presidente Mauricio Macri (2015-2019).

I7 Dominik Schrey recuerda que la "auratización" de los soportes analógicos a raíz de la digitalización contemporánea se basa en una confusión entre "lo analógico" y "lo indicial" (2014:30) y retoma la crítica formulada por Jonathan Sterne (2006) en contra de la postura metafísica y nostálgica que proyecta más "vida" - autenticidad, aura, alma, o esencia - en los soportes analógicos que en los digitales. Esta concepción se contrapone a la que han tenido autores franceses, fundacionales de una teoría de la puesta en escena asociada a la fenomenología. André Bazin, por ejemplo, señalaba que "la fotografía se beneficia con una transfusión de realidad de la cosa a su reproducción” (2004: 28). Michel Mourlet (I959) indicaba que "un ojo de cristal y una memoria de bromuro de plata concederían al artista la posibilidad de recrear el mundo a partir de lo que es, y por lo tanto de proporcionar a la belleza las armas más afiladas de lo verdadero".

I8 Pensamos en el "grano" de la imagen pero también en la noción del "grano" de la voz según Barthes (I986: 262-263). 
La multiplicación e incluso la "remediación" de antiguos medios ${ }^{19}$ en el film apuntan fundamentalmente a construir un registro de autenticidad. Como aclara Dominik Schrey al comentar casos de "nostalgia analógica", "los signos específicos de mediación que parecen desviar la atención de la inmediatez del sonido grabado crean, contraintuitivamente, una experiencia de fuerte proximidad sensorial" (2014: 32). Si se aprecian los medios analógicos por su imperfección, su fragilidad, su falta de transparencia y de nitidez, no es solo porque todos estos defectos se han convertido en huellas de un tiempo perdido, ${ }^{20}$ sino porque afectan también la memoria humana. Esta cercanía mítica entre medio analógico y memoria explica esa "nueva práctica mnemónica" que, según van der Heijden, "no busca transparencia pero refiere explícitamente a la tecnología de los medios propiamente dicha en el proceso de reconstrucción de memoria" (20I4: II6) ${ }^{21}$.

En síntesis, Sinfonía para Ana confirma de modo insistente cómo la memoria es por esencia mediatizada y pone énfasis en el poder de la voz grabada como instancia unificadora de los diferentes medios de transmisión del pasado. En ese aspecto reside, desde nuestro punto de vista, uno de sus caracteres distintivos respecto del cine de ficción político sobre la década de los setenta y, también, del acercamiento documental a la temática: el film de Ardito y Molina inocula en su puesta en escena, a través de la reflexión sobre la mediatización, los procesos memorialísticos gracias a los cuales construye su representación del pasado.

\section{LA LEY DEL DESEO}

En Desearás... también la voz de Ofelia irrumpe desde la primera escena, pero fuera de campo y no alude a las circunstancias presentes de la grabación sino que cuenta un episodio de la infancia del personaje. El objeto mediático central de esta escena-prólogo es un televisor, en el que las dos hermanas protagónicas de niñas miran fascinadas la imagen en blanco y negro de un cowboy andando a caballo. Esta visión provoca en Ofelia un movimiento de imitación (cabalga literalmente un almohadón) que la lleva camino

I9 Según Jay David Bolter y Richard Grusin, la remediación es el proceso a través del cual los medios "se apropian de las técnicas, las formas, y la significación social de otros medios e intentan rivalizar con ellos o reactualizarlos con el fin de darles un mayor quantum de realidad" (I999: 98).

20 Como escribe Thomas Levin, "en la era de las grabaciones y las reproducciones digitales, el sonido del error ha cambiado significativamente: el momento del rasguño [de una púa, por ejemplo] no es más el signo de una deficiencia de funcionamiento sino mayormente la marca nostálgica de una pasada era de reproductibilidad mecánica, que, podría decirse, se ha vuelto aurática" (citado por Schrey, 20I4: 32). 2I Por otra parte, cabe indicar que, como se desarrolla en una nota subsiguiente, la presencia escénica constante de los soportes analógicos fue una marca fundamental un sector del cine de la época. Esto se observa nítidamente en películas como The Conversation (Francis Ford Coppola, 1974) o Blow Out (Brian de Palma, I98I). 
recto hacia el orgasmo ${ }^{22}$. La escena, plena de efectos desbordados (ralentí, primerísimo primer plano del rostro de la niña, simbolismo obvio de una serpiente, voces en eco... ${ }^{23}$, está acompañada de una música dramática extradiegética hasta que irrumpe la voz en off de Ofelia adulta para comentar: "El día que tuve mi primer orgasmo, conocí el efecto de los barbitúricos. Mi mamá me diagnosticó epilepsia y me medicó sin dudarlo”. Luego la voz atraviesa el tiempo, y el discurso que comentaba la infancia continúa en el presente, el cual aparece en unos planos en ralentí de Ofelia adulta galopando al lado de su novio (Andrés) en una playa de tarjeta postal24: "Sus pastillas borraban todo. Pero nada borró ese primer ardor. Desde ese día quería volver a sentirlo siempre. Volver a arder”. El efecto kitsch de las imágenes de los caballos en la playa, en las que se insertan los créditos iniciales, es reforzado por la canción sentimental extradiegética: "Por el amor de una

22 En línea con nuestra interpretación de esta obra, no podemos dejar de subrayar que el western fue históricamente un género asociado a valores de masculinidad y consumido por un público, mayoritariamente, de varones. Asimismo, una de las características de este género cinematográfico es la violencia - sintéticamente podríamos decir que el western reelabora de múltiples modos la fundación violenta de una nación- ejercida a través de las armas, de la fuerza física y de la potencia masculina. El caballo es un animal que simbólicamente se encuentra consustanciado con estos caracteres.

23 La composición visual y sonora de este film - y de otros que hemos mencionado ya, como Rojo y El ángel - remite ostensiblemente a una zona de la cinematografía popular de la década de los setenta, en la cual se entremezclan realizadores y géneros de distinta laya pero con un rasgo en común: la estilización de las imágenes, el barroquismo escénico, el desvío del realismo cinematográfico a través de los usos del ralentí, del zoom, de las miradas a cámara y de una paleta de colores saturados. A nivel internacional, estos imaginarios estéticos recalan en el cine del primer Brian de Palma (algunas conexiones con Sisters, I974, son notables), de John Boorman (hay guiños a Deliverance, traducido en la Argentina como La violencia está en nosotros, 1972) y de William Friedkin, entre otros. En algunos de ellos, particularmente en De Palma, el giallo italiano resultó una fuente de inspiración, puesto que estilizó expresiones de violencia, sexualidad y traumas sociales configurando así una suerte de subgénero, o filone, de clase B. Creemos que este es el principal intertexto cinéfilo de Desearás... En un excelente artículo sobre la película de Kaplan, Valeria Arévalos y Viviana Montes (2018: I) dan cuenta de otras referencias posibles - y a nuestro entender, pertinentes - para pensar este film. Según las autoras se trataría de un "sexploitation-camp, hijo no reconocido de Armando Bó y Pedro Almodóvar, que, además, postula un juego de seducción entre géneros cinematográficos como el melodrama, la parodia y la comedia...”.

24 Arévalos y Montes (2018: 3, 7) explican la multiplicidad de funciones que el caballo adquiere en el sistema significante de un film que abunda en metáforas. A la aparición de Ofelia cabalgando en la playa, se suma la presencia del caballo en el espacio de la fiesta de casamiento y su inmediata y escasamente elegante defecación - no por el acto en sí, sino por el modo que es mostrado en un plano cercano-; así como la clausura del film en la cual Carmen - "Mami", dirá Andrés mientras el soundtrack nos deleita con "Yo quiero a Lola" de Palito Ortega- se lanza al reencuentro de su objeto de deseo (Andrés) montada también en un caballo blanco. Para completar este cuadro de referencias cruzadas, recordemos que la secuencia inicial de Fiebre (Armando Bó, 1972) es protagonizada por Isabel Sarli atravesando el campo a caballo y que, en dicha obra, ambientada en el mundo de la hípica y de lo ecuestre, la protagonista mostraba su deseo por el miembro viril del equino. Durante esos mismos años, Sandro irrumpía en una playa en los créditos iniciales de Gitano (Emilio Vieyra, 1970) montando a pelo y cantando sobre un caballo amarronado, en cuero y con unos resplandecientes pantalones blancos. Roberto era el gitano, el otro, el salvaje, así como en Desearás... Andrés ocupa el lugar del extranjero, poco adepto a algunos rituales de la civilización. 
mujer" en la versión de Julio Iglesias (sobre la que volveremos más adelante). La voz de Ofelia va bajando de tono hasta murmurar las últimas palabras "volver a arder" -frase que le da título al tema instrumental que funcionará como leitmotiv de la película- en las que se oye claramente el eco de un micrófono, subrayando la presencia de un dispositivo de grabación. Pero como ocurre en Sinfonía... este signo de mediación no hace sino aumentar el carácter sensual de la voz, la impresión de su presencia física.

Esta secuencia de apertura anuncia la preponderancia que tienen a lo largo del film los aparatos tecnológicos de comunicación (ahora la televisión, más tarde el magnetófono) y las canciones de los setenta, remarcando su valor placentero. Uno de los intereses de esta película es que su puesta en escena de las canciones y de los objetos tecnológicos de época revela que, más allá de constituir mediaciones o vehículos que movilizan al placer, son condiciones necesarias de este, y nos da a pensar nuestra propia relación espectatorial con ellas.

Al contrario de la voz de Ana en Sinfonía..., que es anterior a las imágenes y se inscribe directamente en una cinta que la materializa y la historiza, la voz de Ofelia surge después de unas imágenes estilizadas para comentarlas y es disociada de su fuente visual. Por un lado, esta estrategia tiene probablemente que ver con una intención del director de crear un efecto de suspenso respecto de la primera aparición visual de Carolina Ardohaín, en una obra que ha sido anunciada como "la película de Pampita". Pero esa voz desencarnada inicial predice lo que será el funcionamiento global del film, que otorga mayor fuerza provocativa y erótica a las voces y a sus discursos, que a los cuerpos. En efecto, estos son registrados con los artificios propios de la visualidad de los setenta conectada, seguramente, con el cine publicitario ${ }^{25}$. No obstante, aquello que se ve se vincula más con los elementos de cierto "soft porno": es el reino de la lubricidad; de los tendones, músculos, miembros y bustos marcados; de las transparencias y humedades sobre y de la piel. Esta apuesta visual, que ha sido señalada por la crítica unánimemente como deudora del kitsch $^{26}$, conduce hacia la deserotización y hacia la parodia por las vías de la hipérbole y del anacronismo estético. Como indica Gaspar Zimerman, la película "rompe algunos tabúes, como mostrar penes o a una nena acabando, pero su osadía pasa más por lo verbal que por lo visual. Escuchamos decir 'pito', 'orgasmo', 'vagina', 'verga', pero

25 De hecho, Diego Kaplan tiene una dilatada experiencia como director publicitario. Fue responsable de más de 300 comerciales audiovisuales realizados en el transcurso de I5 años.

26 Este ensayo no se internará en la problemática de lo kitsch para analizar la obra, por dos razones. La primera: se trata de un concepto sobre el que se han escrito bibliotecas pero que, en la mayor parte de sus utilizaciones contemporáneas, se ha transformado en una etiqueta para despachar hacia el terreno de la cultura de masas a materiales artísticos de diversa laya sin mayores justificaciones analíticas. En segundo lugar, porque el emparentamiento inmediato de este film con lo kitsch, nexo que en la superficie de la obra parece resultar obligado, nos lanzaría en un terreno estético-teórico en el cual se desdibujarían las intervenciones políticas y culturales sobre los setenta que nos importa explorar en nuestro texto. 
es curioso: aquí la mayor parte de la gente tiene sexo vestida" (en Clarín, 04/10/2017). Es momento de postular - o de volver a subrayar - una de nuestras ideas-fuerza: lo que $\mathrm{Zi}$ merman critica como una debilidad nos parece sintomático de los poderes que no solo Desearás... sino varios otros films contemporáneos sobre los setenta dan al sonido en su construcción de esta época como un tiempo "caliente" de la historia.
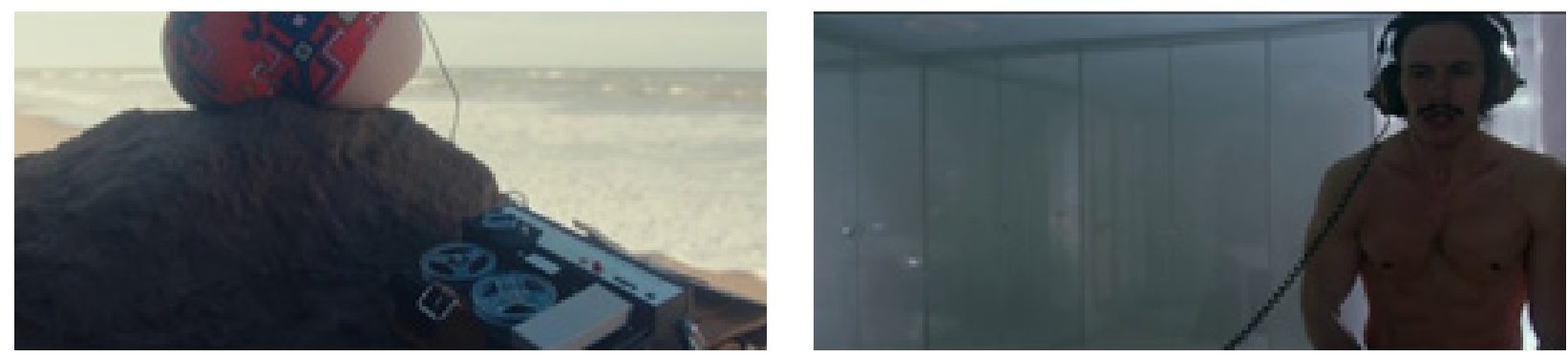

Figuras 7 y 8: erotización de los artefactos de grabación y reproducción sonora en Desearás...

Las cintas que contienen la voz de Ofelia y el magnetófono que permite escucharlas aparecen desde las primeras secuencias posteriores a los créditos y reciben un papel clave en la estructura temporal del film (permiten introducir los primeros flashbacks) y en la revelación de los conflictos pasados y presentes entre los protagonistas.

Es Carmen (Andrea Frigerio), la madre de las hermanas, la que entrega las grabaciones de Ofelia (Carolina "Pampita” Ardohaín) a Lucía (Mónica Antonópulos), sin saber qué contienen: las presenta como posibles "canciones para la fiesta” de boda de Lucía, lo cual resultará irónico retrospectivamente, ya que esas cintas agudizarán el deseo de Juan (Juan Sorini), el marido de Lucía, por Ofelia. Desde la primera escena entre Lucía y Juan, un primer plano destaca la mirada del segundo que, mientras besa a Lucía, queda fascinado por las cintas que esta ha dejado en desorden en la cama al lado de su vestido de boda; el montaje insiste en el efecto poderoso de esos objetos sobre Juan, mediante dos primeros planos que nos permiten visualizar sus etiquetas ("Ofelia, 5.9.I965", "Ofelia, 2.4.I962") y el nombre de la marca de la segunda (Magnasonic).
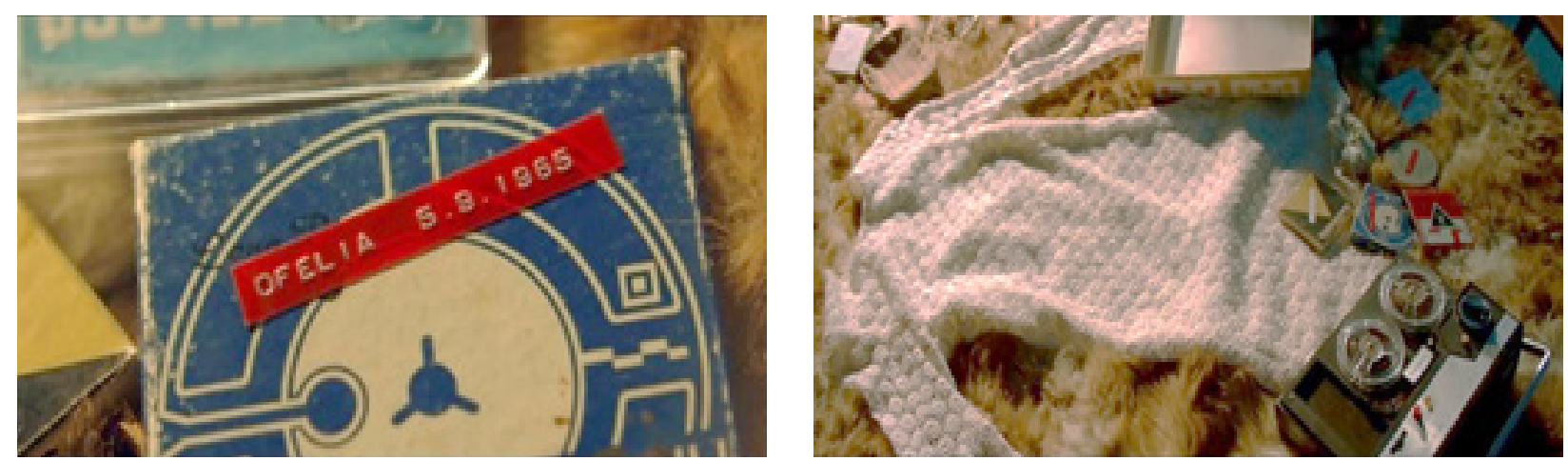

Figuras 9 y Io: fotogramas del inicio de Desearás... (20I7) 
Al día siguiente, después de la irrupción de Ofelia y de su encuentro-flechazo con Juan, este toma el magnetófono en el cuarto de baño y se masturba escuchando el audio con el relato de Ofelia (figura 8). Su deseo, ya encendido, se desencadena por la mediación tecnológica de la grabadora que reproduce la voz de Ofelia y provoca su imaginación erótica. La visualización de los descubrimientos sexuales que narra Ofelia (los flashbacks) puede así entenderse como el producto de las fantasías de Juan. En este pasado fantaseado, vemos las relaciones de las hermanas adolescentes con dos muchachos, y la diferencia entre Ofelia ("caliente", que disfruta especialmente del sexo oral) y Lucía ("fría" o "frígida", desprovista de sensibilidad sexual). De vuelta en el presente, Lucía y luego Ofelia buscan el grabador escondido por Juan, y la oposición entre ellas se cristaliza en su actitud frente al gesto mismo de grabar su voz. Frente a Lucía quien dice tener demasiada memoria ("No necesito estar grabándome para recordar", "No me olvido de nada"), Ofelia justifica el uso del grabador como soporte mnemónico ("Grabo para recordar. Vos lo dijiste: lo hago porque después me olvido"). Este diálogo tiene lugar en un cuarto atestado de espejos (objeto emblema para exponer el conflicto identitario propio del melodrama), manifestando el valor especular del grabador dentro del film. En efecto, la presencia de ese objeto que materializa el paso del tiempo remite cada personaje a sus deseos: Lucía a su deseo de olvidar el pasado y también de deshacerse de su pulsión voyerista que la hace espiar a su hermana, Ofelia a su deseo de recordar, Juan a su deseo por Ofelia. En una escena, la imagen de las cintas girando se sobreimprime a un plano del rostro de Ofelia mientras monta a Andrés, manifestando claramente su estatuto como objeto especular del deseo: el grabador y las cintas analógicas no solo sirven como vehículos de fantasías y metáforas de la memoria humana, sino que materializan el funcionamiento mimético y circular del deseo. Al final, Juan entregará a Andrés (Guilherme Winter) el grabador de Ofelia, como motivo que explica el carácter inexorable de su deseo por ella.
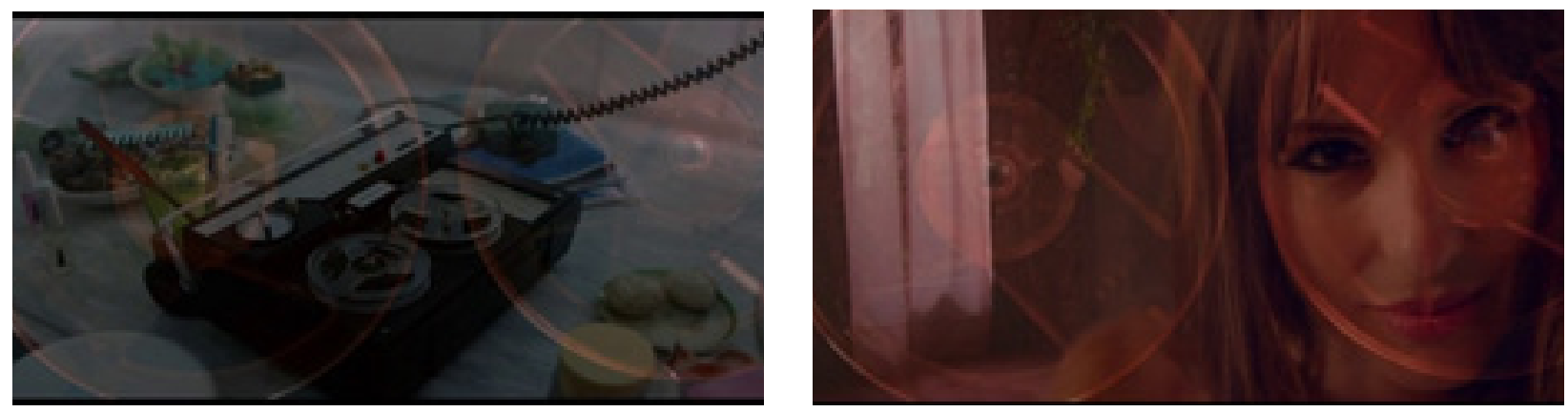

Figuras II y I2: el grabador, objeto que cristaliza el deseo en Desearás...

Como en Sinfonía..., la voz registrada en el soporte analógico habla desde un pasado que ha concluido de manera traumática (o sea, que no ha dejado de tener consecuen- 
cias sobre el presente). Pero en Sinfonía... el trauma es político en un sentido estricto: el inicio de la dictadura militar coincide con la desaparición de Ana y su probable suicidio preventivo, mientras que en Desearás... es de índole sexual, aunque de una política de lo sexual que tiene consecuencias trágicas: el deseo de Ofelia y Lucía de dar placer a sus novios de juventud, dos hermanos negros, termina con el suicidio de uno de ellos (se ahorca colgándose de un árbol).

\section{MEMORIA SONORO-ESPACIAL Y ESPACIOS CONTROLADOS}

El espacio cobra un sentido mnemónico si lo consideramos desde el uso de la voz y del relato grabado. Los dos relatos se organizan en torno a un edificio central que tiene un estatuto especial en la memoria histórica-colectiva (Sinfonía...) o en la memoria privada-familiar (Desearás...) de las protagonistas. En Sinfonía..., como dijimos, se trata del Colegio Nacional de Buenos Aires, que constituye el único referente espacial concreto que contextualiza la acción dramática. Es el lugar donde los estudiantes se juntan, se enamoran y planean sus acciones políticas. Ese edificio de techos muy altos favorece un sonido con reverberación, un eco que adquiere valor mnemónico en el marco del relato de Ana: da a sentir que las voces de los chicos del CNBA son voces que Ana va recordando, que emanan del espacio íntimo de su memoria.

En Desearás... el espacio nodal es la casona familiar con piscina, que articula, a través de los fluidos, los traumas del pasado con los conflictos del presente. Situada en medio de la casa, esta cobra protagonismo tanto en el pasado (Ofelia encontró el cadáver desnudo de su padre flotando) como en el presente (desde el momento en que la madre cae al agua vestida, durante la fiesta de boda). Junto con el mar cercano, la piscina justifica que todos los personajes se paseen semidesnudos y da lugar a muchos planos dedicados a los cuerpos que se mueven en el agua, ampliamente musicalizados ${ }^{27}$. La presencia constante del elemento acuático en el film, y por otro lado el papel nodal de las voces (la de Ofelia pero también, como veremos, las de las canciones), sugieren que ambos aspectos está conectados: en Desearás..., la voz "sumerge" al espectador como el agua a los personajes. Resulta sugerente en este sentido la afirmación de Michel Chion según la cual "[el] agua es femenina, el árbol masculino. El agua y la voz son dos imágenes de

27 La música incidental no diegética que acompaña los planos acuáticos (los temas instrumentales "Desearás al hombre de tu hermana" y "Volver a arder"), a cargo de Iván Wyszogrod, tienen caracteres estructurales similares en cuanto a sus movimientos: introducciones melódicas y lentas, un crescendo en el desarrollo y un final a toda orquesta (particularmente la segunda). Piano, trompeta, cuerdas, bajo y batería en la primera y los mismos más piano y oboe son la base de su instrumentación. Sin embargo, merece destacarse que se trata de sonidos sintetizados, artificiales, que remiten a jingles publicitarios o a la artificiosidad de ciertas instrumentaciones de la música ligera italiana de los setenta. Las inserciones 
lo que no tiene espacio ni límites [...]. El árbol, en cambio es un lugar y marca un límite" (I982: I06). Desearás... explota efectivamente esos dos símbolos elementales en relación al placer sexual. En línea con Chion (1982), a sabiendas de estarnos deslizando en el resbaloso suelo de la vulgata psicoanalítica, si el agua connota un placer regresivo (la vuelta al origen de la vida) pero potencialmente infinito que descoloca (la escena de sexo en el barro la noche de lluvia), el árbol figura un límite del placer (la imagen del novio ahorcado en un árbol).

En síntesis, en Sinfonía... la voz tiene un estatuto marcadamente fantasmal: la tecnología analógica permite resucitarla y con ella a toda una época. Construye la historia colectiva, articulando una serie de documentos de archivo, como una puesta en escena nostálgica y afectiva de una memoria íntima. En Desearás... en cambio la voz grabada recibe un valor francamente erótico que repercute en el retrato de los setenta como ambiente afectivo.

Esta perspectiva nos permite afirmar que en la recuperación de los años setenta efectuada por el cine de ficción argentino contemporáneo, las diferentes aristas de los espacios auditivos y sonoros son fundamentales para aludir a las dimensiones culturales y afectivas del periodo representado. Adicionalmente, otro argumento que podría derruir la supuesta impertinencia de poner en contacto obras tan disímiles como las que aquí abordamos, es que la figuración del espacio en la puesta en escena de ambos films expresa situaciones de encierro, de control y de violencia que, de modos más o menos explícitos, comunica un locus de la década de los setenta.

En Desearás... la casa es el espacio de la celebración de una fiesta de casamiento pero es también un lugar de encierro. La diégesis permite suponer que la casa está localizada en algún punto de la costa sur de Brasil o de Uruguay. Como fuese, la diégesis sí informa claramente respecto de la imposibilidad de salir de allí hacia Buenos Aires por el puerto dadas las adversas condiciones climáticas. Las hermanas, sus respetivas parejas y la madre no pueden abandonar un espacio que se torna riesgoso: en esa casa se suicidó el esposo de Carmen, en los alrededores del mismo sitio se colgó el pretendiente de la joven Ofelia. De una terraza de esa casa caerá Andrés quien, antes de ser hospitalizado, se encarga de desfigurar a golpes a Juan Rojo, el novio de Lucía. Las imágenes de estos

musicales de estos temas, que son el leitmotiv del film, pero con sutiles cambios en su instrumentación y en su amplitud sonora, escoltan, indefectiblemente, las escenas de orden erótico-sexual. Las reminiscencias (armónicas, estilísticas e instrumentales) son claramente al "Soleado" (Daniel Sentacruz Ensemble, I974) utilizado por Leonardo Favio en la famosa secuencia del éxtasis edénico-sexual entre Nazareno y Griselda (Nazareno Cruz y el lobo, I975). El ralentí, la circulación del agua, la relación salvaje con la naturaleza y la exposición esplendorosa de los cuerpos de la famosa secuencia de la obra de Favio, parecen haber sido otras de las inspiraciones de Diego Kaplan para rodar las escenas sexuales de Desearás... Por último, resulta pertinente recordar que Wyszogrod fue el responsable de componer la música de los últimos dos largometrajes de Leonardo Favio: Perón, sinfonía del sentimiento (1999) y Aniceto (2008). 
eventos son índices elocuentes de violencia (un colgado, un ahogado, un desfigurado) relacionados con la década que nos ocupa vía el repertorio de canciones (sobre el que volveremos en las siguientes páginas), el vestuario, las referencias a la píldora anticonceptiva y a la escenografía, entre otros elementos.
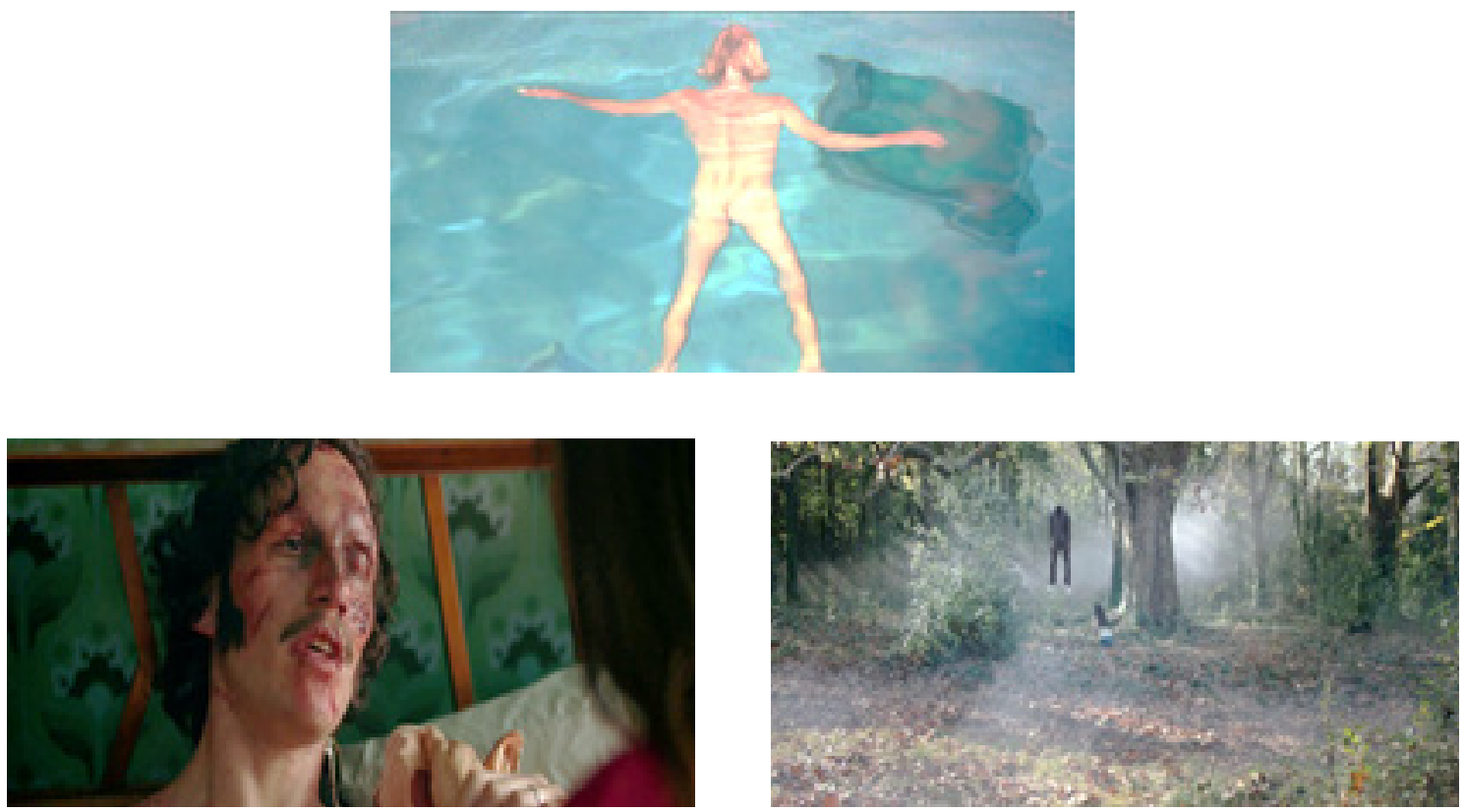

Figuras I3, I4 y I5: Padre ahogado, novio colgado, marido desfigurado en Desearás...

Las miradas, vectores del deseo entre los personajes, también son vehículos de control, que funcionan en acuerdo con la distancia y el emplazamiento que detentan los que observan sobre los que son observados. Durante todo el film, aquellos que miran no se ocupan de obtener revelaciones o de espiar para movilizar la acción de un conflicto, sino que lo hacen para disfrutar escopofílicamente (si se nos permite la torsión terminológica) de los espectáculos que ante sus ojos se representan, o para controlar, no sin cierta desconfianza, las relaciones entre unos y otros. De vigilar y castigar pasamos a controlar y gozar, y en este desplazamiento lo que se mantiene incólume es la sobredeterminación espacial. La consciencia narrativa sobre la orientación de las miradas y la relación de estas con el placer y con el control es absoluta. Se confirma palmariamente en la única escena en la cual se quiebra la regla de la mirada prohibida a cámara, dando cuenta de una cesura en el relato. Reunida con sus hijas jóvenes, mientras toman una copa, Carmen les entrega las "píldoras de la felicidad" (anticonceptivos), las que supuestamente solo pudo comprar en los Estados Unidos, cuando dirige su mirada frontalmente al lente de la cámara y señala: "Hay países en las que están prohibidas. Hay gobiernos que no nos quieren ver gozar" ${ }^{28}$.La casa, entonces, no solo es un espacio de confinamiento, sino que 28 Esta afirmación posiblemente remita al decreto $N^{\circ} 659$ del 28 de febrero de I974 firmado por José 
figura la imposibilidad de mantener una intimidad no controlada por la mirada de los demás. En otras palabras, el otro está en todas partes: Juan observa concentradamente a Lucía cuando interpreta “Tómame o déjame” (Juan Carlos Calderón, 1974) desde el piso superior del inmueble. Ofelia mira a su madre quien, en un trance místico-etílico, habla con su padre muerto y cae en la piscina. Andrés, petrificado, fija sus ojos en el espectáculo de Ofelia y Juan cuando bailan el country-pop “These Boots Are Made For Walkin”" (Lee Hazlewood, I966). Lucía comprueba, a través de una ventana, las dificultades que su hermana encuentra para tener sexo con Andrés.

En Sinfonía... estos caracteres cambian drásticamente porque, justamente, la política del espacio y de la mirada que propone el film es absolutamente diversa. Como anticipamos, la puesta en escena está organizada sobre la base de una estética de los fragmentos: planos cortos, primeros planos, planos detalle, primerísimos primeros planos. En el orden del sonido, específicamente, en el de la voz en off que relata la historia se sueldan estos fragmentos visuales. Sin embargo, con excepción de unos pocos exteriores (espacios que carecen de edificios que demuestren el paso del tiempo), los interiores del colegio son los únicos que merecen encuadres más amplios. En términos de producción esto se explica porque la estructura edilicia del CNBA no ha cambiado sustancialmente desde la década de los setenta a la fecha. El colegio es "patrimonio histórico" de la Ciudad Autónoma de Buenos Aires. En términos estéticos, el colegio, con el avance de la violencia política y con el golpe de Estado, deviene una institución en la que se acentúan las funciones de vigilancia y persecución sobre el cuerpo estudiantil. Los planos más amplios usados por los directores promueven que un espacio que inicialmente era de ebullición política, amorosa y amistosa se convierta en un lugar ominoso, excesivamente laberíntico, en el que resulta imposible encontrar intimidad y escapar del control de las autoridades. En este sentido, los planos de corta duración, pero profundamente sintomáticos, del rector Aragón encerrado, aislado en los altos del edificio, que solo puede observar lo que ocurre a su alrededor mientras resiste, anticipan el futuro cruento que se cernirá sobre el colegio y sobre el país.

López Rega y Juan Domingo Perón, en el que se dispuso un control muy estricto de la comercialización de las píldoras anticonceptivas con el fin de desalentar su uso. Este decreto se mantuvo durante el gobierno de facto a partir de I976. El texto de Carmen es incierto porque no se refiere directamente a la Argentina; además, la píldora siguió siendo accesible en el país para las clases medias y acomodadas a pesar de las restricciones. Karina Felitti (2012) examina en detalle el derrotero de la píldora en la Argentina y sus implicaciones de orden sexual, cultural y político. Según la autora la píldora se vio, en las décadas de los sesenta y setenta, como símbolo del nuevo lugar de la mujer en la sociedad y de la revolución sexual en curso pero también como herramienta de control social. El problema de la libre exploración del placer sexual y del control forma parte de la historia de los anticonceptivos y también de las preocupaciones dramáticas del film. 

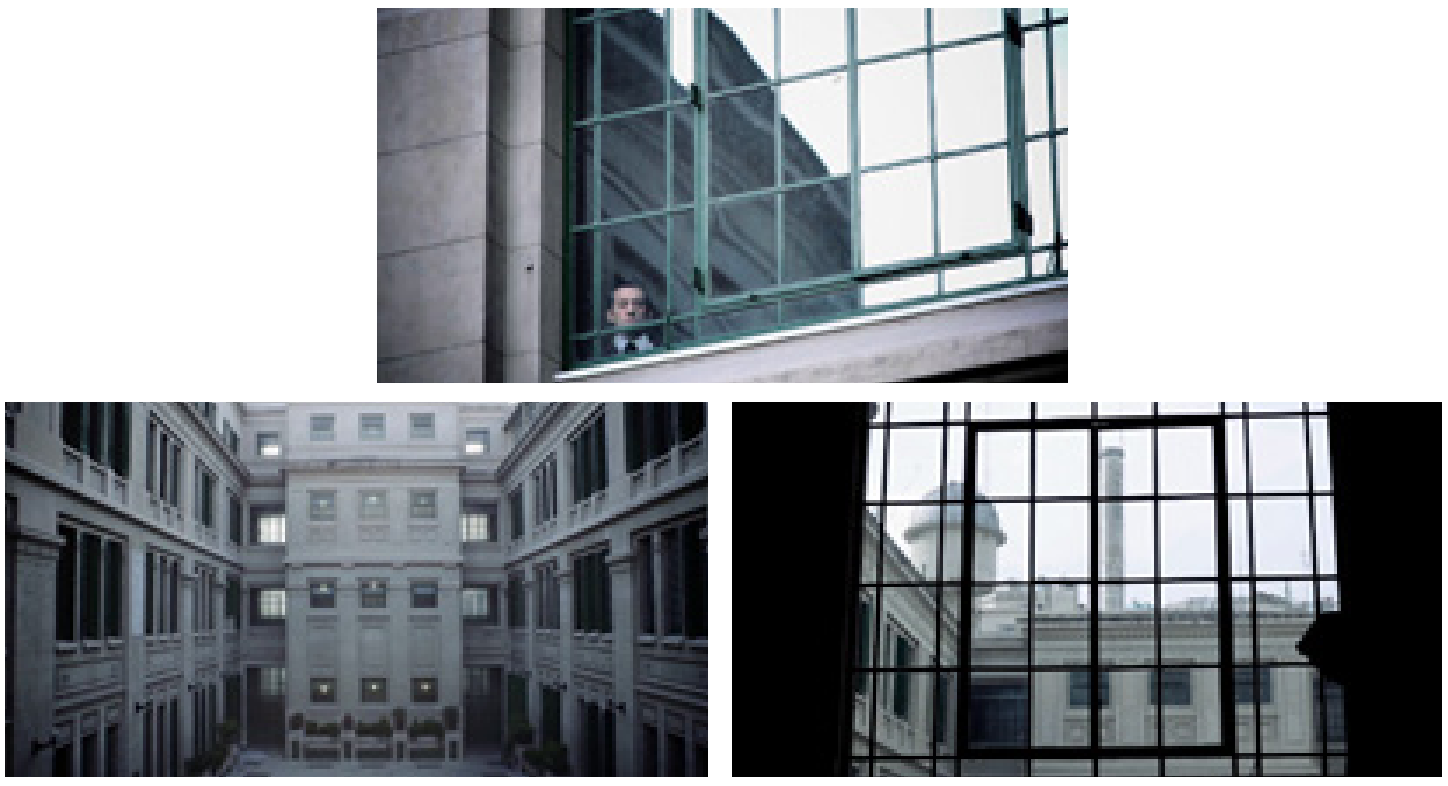

Figuras I6, I7 y i8: fotogramas de Sinfonía para Ana (2017). El rector Aragón y vistas interiores del CNBA: las cuadriculas refuerzan los conceptos de vigilancia, control y encierro

\section{LA MECÁNICA AFECTIVA DE LAS CANCIONES}

Hasta aquí, nos hemos detenido en el papel que tienen las voces grabadas y reproducidas de las protagonistas como instancias desde las que se construyen la memoria de los primeros años setenta y el espacio diegético. A la par, hemos introducido alusiones al rol similar que cumplen las canciones diegéticas de la época, asociadas ellas también a unos dispositivos de reproducción analógica. En ambas películas, junto con la reproducción de las voces de Ana y Ofelia, las canciones cumplen un papel esencial en la elaboración de una memoria afectiva de los setenta, en la cual se anudan sensualidad y violencia.

Del mismo modo que las confidencias de Ana y Ofelia son explícitamente mediadas por el magnetófono, las canciones más potentes que se auricularizan, en su mayoría temas de la época, se vinculan con distintas fuentes diegéticas, entre las que cabe destacar el tocadiscos, origen sugerido de la canción principal de Sinfonía... y de varias canciones de Desearás...
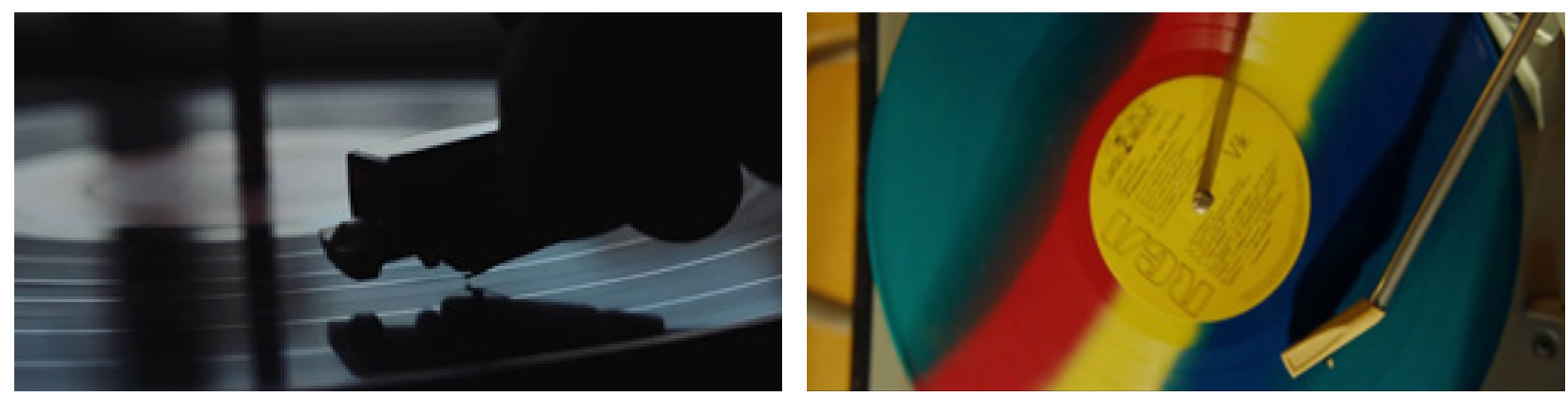

Figuras I9 y 20: tocadiscos girando en Sinfonía... y Desearás... 
El magnetófono y el tocadiscos valen por la calidad del sonido que proporcionan -apreciado por ser cálido, analógico, valvular, en contraposición con el sonido producido por muestreo digital, supuestamente más frío e incluso "metálico"-, por su materialidad táctil - opuesta a la virtualidad de los soportes digitales - así como por el ritual y la experiencia de escucha atenta que implican. Las cualidades de calor, materialidad, experiencia y ritual se aplican a la reconstrucción mnemónica y a las relaciones afectivas de los setenta. Si, más allá de la función de emisión sonora, nos detenemos en las propiedades físicas de los artefactos, comprobaremos que se trata de objetos que producen un movimiento giratorio mecánico. En Desearás... se dedican múltiples planos detalle al magnetófono. De hecho, la rotación de las bobinas es la que se utiliza para realizar la primera transición entre el presente y el pasado de la narración a través del relato de Ofelia. En Sinfonía..., hemos señalado ya cómo la economía objetual de una puesta en escena construida a partir del ensamblaje de plano cortos recupera en diversas ocasiones artefactos analógicos que reproducen sonido: el televisor, la radio y el tocadiscos. El plano de apertura de la escena en la cual Ana y Lito tienen su primer encuentro sexual muestra el movimiento giratorio de un tocadiscos que se enlaza con los LP que Lito enseña a Ana al llegar a la habitación y con la escena de la despedida final de los dos jóvenes enamorados, único momento en el que una canción adquiere el imperio absoluto sobre la serie sonora. Con esto queremos señalar que los trabajos de la memoria escenificados en ambos films están montados sobre artefactos técnico-mecánicos que generan fricciones y desplazamientos físicos y, por lo tanto, involucran transformaciones materiales de las cosas. Los sonidos del pasado se actualizan en el presente narrativo a partir de su ligazón con una actividad humana que los quita de su inercia, de su reposo, para volver a construir sentidos. De acuerdo con Michel Chion (2018: I3I), el ocultamiento o el énfasis de los "indicios sonoros materiales" puede contribuir a la creación de universos metafísicos y cumple un rol central en las cualidades dramáticas de las películas. Estas particularidades del sonido se combinan con las propiedades melódicas y textuales, y con las referencias intertextuales y culturales de las canciones que se escuchan en ambos films.

A continuación examinaremos las canciones utilizadas en las obras. Prestaremos mayor atención a los temas que, a nuestro entender, condensan las búsquedas narrativas y expresivas de las películas y comunican la clave de lectura de estas sobre el periodo representado. Demostraremos cómo en estos temas musicales - su puesta en escena, su letra, su instrumentación, su sentido cultural - se cristaliza el valor afectivo y mnemónico o la textura de los primeros años setenta ${ }^{29}$.

29 Aludimos a la noción de "canción-cristal" que propone Phil Powrie (20I7) para designar aquellas canciones que, en una película, no expresan simplemente los procesos y afectos de los personajes, sino que surgen al mismo tiempo que estos afectos, los moldean y los profundizan (en síntesis, los performan). 


\section{LA SOLEDAD ES UN AMIGO QUE NO ESTÁ}

En Sinfonía para Ana existen dos usos distintos de las canciones. Por un lado, en tres momentos se escucha a uno o varios personajes entonar una canción; por otro, la secuencia culminante del drama está acompañada por una canción de Sui Generis ("Cuando ya me empiece a quedar solo", I973). Las primeras son canciones diegéticas mediante las que los personajes hacen cosas: (a) expresan e inscriben sus emociones individuales en un momento de duelo nacional (la breve canción que canta la empleada doméstica Rosa cuando muere Perón) ${ }^{30}$; (b) manifiestan su afán militante y su fraternidad en solidaridad con una larga tradición de lucha internacional ““¡Ay, Carmela!”, cantada por los estudiantes dentro del colegio que acaban de tomar, tiene una fuerte carga cultural e intertextual) $)^{35}$; (c) delatan su lucha cuando ha pasado a ser clandestina (la canción montonera que canturrea Ana distraídamente mientras estudia en su cuarto, asustando a su padre quien le prohíbe volver a cantarla) ${ }^{32}$. Estas tres canciones relacionan directamente a los personajes con sus afectos y compromiso político. No es casual que en los tres casos las canciones sean interpretadas por mujeres, esto se debe particularmente al rol cada vez más preponderante que estas fueron adquiriendo dentro del movimiento peronista y a que, en el marco de la diégesis, son ellas quienes ocupan el lugar de la enunciación y el protagonismo del film.

La canción de Sui Generis se distingue de las demás por su estatuto ambidiegético y por constituir un objeto cultural con connotaciones claramente reconocibles por el público argentino - Sui Generis es un grupo icónico del rock nacional-y además con

30 "Rosa, mi Rosa, '¿qué va a ser de los pobres ahora?' me dijo y cantó” dice Ana, observando de espaldas a Rosa, una vez que esta ya ha cantado. Esta organización de la temporalidad narrativa ilustra el modo general en el que opera la rememoración en Sinfonía para Ana: primero se representa la experiencia sensorial, solo después esta se convierte en discurso oral, se pone en palabras. La canción interpretada por Rosa a cappella es una baguala, género melancólico del nordeste argentino, a través de la cual ella manifiesta su origen étnico, cultural y de clase, y el hondo sentimiento de pérdida ante el fallecimiento de Perón.

3I La canción popular “¡Ay, Carmela!” se vincula con la lucha de los españoles contra las tropas de Napoleón en I808; en el siglo XX, fue retomada por los republicanos durante la Guerra Civil (I936-I939), causa con la que ha quedado identificada a nivel internacional desde los films de Basilio Martín Patino Canciones para después de una guerra (I976) y de Carlos Saura iAy, Carmela! (1990). Entre los planos que desfilan mientras se oye la canción en Sinfonía..., cabe destacar uno que muestra carteles de Pinochet con los slogans: “¡Alto a la matanza! ¡Solidaridad con Chile!”. Asimismo, la canción ya había sido reapropiada por partidarios del primer peronismo y era interpretada por los hijos de aquellos militantes, pertenecientes a la juventud peronista, la noche del ig de junio de i973, durante la vigía ante el inminente retorno de Perón al país (véase Romero, 2006: 2). Esta última referencia permite hilar varias luchas en términos históricos y, en la coyuntura que narra el film, la fraternidad (no exenta de conflictos) entre los sectores peronistas y socialistas de la juventud con participación política en el Colegio Nacional de Buenos Aires. 32 "Con los huesos de Aramburu vamo' a hacer una escalera, ipara que baje del cielo nuestra Evita montonera!". 
referencias intertextuales al cine del país. "Cuando ya me empiece a quedar solo" pertenece al segundo álbum del grupo, Confesiones de invierno (1973). Si bien no se ve la fuente diegética de la canción, se asocia con los vinilos de rock y tocadiscos que Lito tiene en su cuarto, donde transcurre la escena; se visualiza el primer LP de la banda, Vida, entre los discos de Lito en la escena antes mencionada. El tema musical se inserta en un momento de clímax, cuando la lucha estudiantil parece haber perdido toda esperanza de éxito y los novios acaban de recibir la noticia de su inminente separación (Lito tiene que exilarse en Brasil con su familia). A las primeras notas de piano de la canción se superpone la voz de Ana diciendo: "Hagamos el amor" y luego surge la voz de Nito Mestre33, mientras los adolescentes se abrazan llorando:

Tendré los ojos muy lejos y un cigarrillo en la boca,

El pecho dentro de un hueco y una gata medio loca.

Un escenario vacío, un libro muerto de pena,

Un dibujo destruido y la caridad ajena.

Un televisor inútil eléctrica compañía,

La radio a todo volumen y una prisión que no es mía.

Una vejez sin temores y una vida reposada,

Ventanas muy agitadas y una cama tan inmóvil.

Y un montón de diarios apilados y una flor cuidando mi pasado

Y un rumor de voces que me gritan y un millón de manos que me aplauden

Y el fantasma tuyo, sobre todo cuando ya me empiece a quedar solo...

Esta enumeración negativa - proyectando un antimodelo de los valores del rock y de la cultura juvenil de la época ${ }^{34}$ - acompaña una serie de primerísimos planos de los rostros, fracciones de los cuerpos de Ana y Lito (sus hombros, sus manos), imágenes que subrayan la tristeza anticipada de su separación mucho más que el goce de la unión sexual. El registro vocal y musical pausado de esta canción que tiene rasgos tangueros ${ }^{35}$, una cadencia lenta y una orquestación discreta (nunca perjudica la claridad de la letra), refuerza a primera vista el carácter intimista de la escena.

Sin embargo, la letra de la canción, en sí misma desprovista de referencia política, inspira la inserción de algunos planos exteriores a la escena amorosa: las palabras "Un televisor inútil..." se superponen a un plano del padre de Ana mirando la televisión (conformando una imagen de la alienación por la industria del divertimiento masivo). Durante la frase que sigue: "La radio a todo volumen y una prisión que no es mía" aparecen

33 La de Charly García, quien compuso las letras, se suma a partir del verso "Un escenario vacío...”.

34 Véase el análisis de Adrián Pablo Fanjul (2014: 268-269).

35 Sobre la "cancionística rockera de filiación tanguera", véase Guillermo Anad (2008). 
imágenes de archivo que aluden al golpe de Estado responsable de la separación forzada de los chicos. El montaje aprovecha las evocaciones negativas de la canción en torno a los términos "televisión", "radio" y "prisión" para mostrar que la historia de los jóvenes amantes está determinada por el contexto mediático (alienante) y represivo de su épo$\mathrm{ca}^{36}$. Asimismo, esta escena provee una revisión de la canción: el estado de melancolía futura cobra otro matiz desde la imagen televisiva de los militares que se impone en medio de los planos íntimos de los adolescentes; la proyección individual de una soledad íntima - que plantean varias canciones del mismo álbum de Sui Generis ${ }^{37}$ - se vincula con una causa política y adquiere así un valor colectivo.
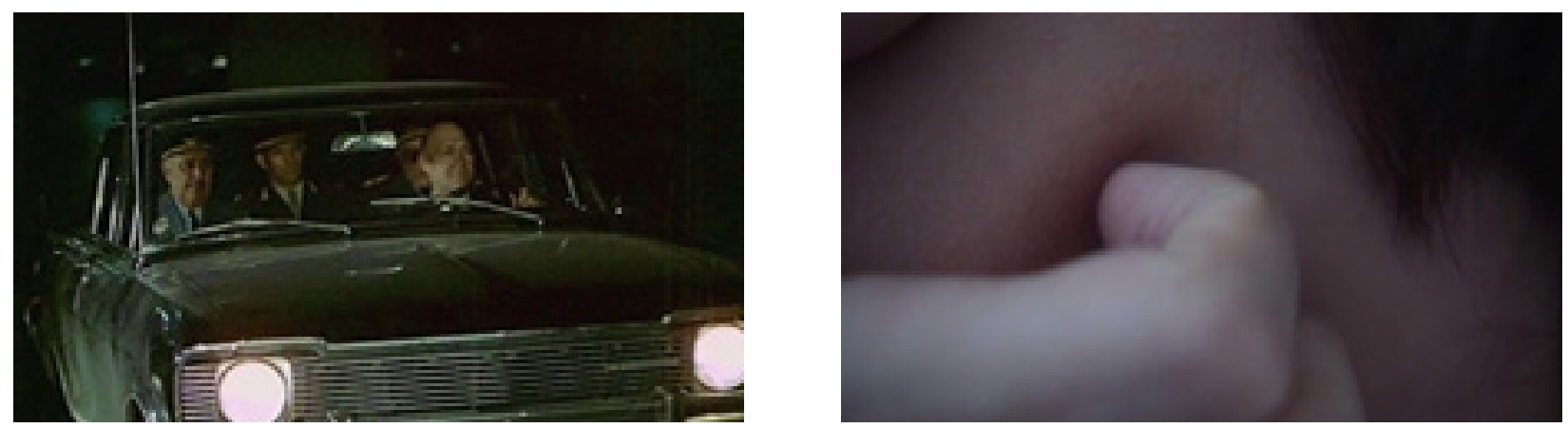

Figuras 21 y 22: se insertan imágenes del golpe militar entre los primerísimos planos de la escena de amor entre Ana y Lito, acompañada por la canción "Cuando ya me empiece a quedar solo"

Este matiz político viene también del carácter emblemático que tiene la banda de rock Sui Generis en la cultura juvenil del período. Más allá de esta canción particular, Sui Generis, que dio sus primeros recitales en el Colegio Nacional de Buenos Aires a fines de los sesenta, se asocia con el espíritu de rebeldía de los estudiantes secundarios. Si en sus primeras canciones se trataba ante todo de la rebelión adolescente contra la familia, en la época a la que remite la película el grupo había lanzado un álbum de canciones políticas: Pequeñas anécdotas sobre las instituciones (1974). Aunque la canción "Cuando ya me empiece a quedar solo" procede del disco anterior (I973) es posible sostener que están presentes en la memoria del público los títulos más comprometidos que la siguieron ${ }^{38}$.

36 Es interesante notar que si, por un lado, el sistema de valores anticonformista de Sui Generis y de los adolescentes "rebeldes" de la época "rechaza la radio y la televisión, buscando un contacto directo con el pueblo" (Fanjul, 20I4: 269), la película Sinfonía... a la vez retoma esta crítica y acude masivamente a esos medios (televisión y radio), entre otros, para reconstruir la época, e incluso proyecta en ellos cierta nostalgia: cuarenta y cinco años más tarde, otros valores se combinan con las nociones de soledad y de "eléctrica compañía".

37 Los títulos "Aprendizaje" o "Un hada, un cisne", por ejemplo, plantean también un futuro más oscuro y una aventura individual más que colectiva - respecto del primer álbum Vida-.

38 Cuando el rock ya era un género adulto, Sui Generis remitía a un estado de adolescencia, lo cual, en términos referenciales, es absolutamente coherente con el universo diegético de la película: se trataba de un grupo aceptado por los padres burgueses en una época en que el rock era sinónimo de rebelión. En Pequeñas anécdotas sobre las instituciones, en cambio, el rock deviene canción política. 
Se podría sostener que el mero empleo de una canción de rock de los setenta en vínculo con la dictadura es una manera de reivindicar el espíritu de resistencia identificado con este género musical - perspectiva que ha recibido cuestionamientos ${ }^{39}$ - que fue reprimido como "subversivo" por los militares. Pero aquí interviene también una referencia intertextual que refuerza y afina este valor de resistencia: la elección de esta canción de Sui Generis en una escena de amor entre dos jóvenes separados por la dictadura remite al uso de las canciones del mismo grupo que encontramos en La noche de los lápices (Héctor Olivera, I986), antecedente de Sinfonía... en su figuración de la represión de estudiantes. La noche de los lápices - una película que marcó el cine testimonial argentino de los ochenta- muestra cómo en I976, un grupo de siete estudiantes secundarios de la ciudad de la Plata fueron secuestrados y torturados en un centro clandestino de detención. Desde sus celdas separadas, los muchachos entonan juntos "Canción para mi muerte" (incluida en Vida) y "Rasguña las piedras" (de Confesiones de Invierno, I973). Estas canciones que pertenecen al repertorio clásico del rock nacional y operan como símbolos de la cultura juvenil de los setenta reciben desde esas secuencias de canto colectivo nuevos valores: simbolizan su unión solidaria (la voz traspasa las paredes), su esperanza, su inocencia, su deseo de no ser olvidados (véase Carrillo Rodríguez, 20I8: IIO-II2), valores que se transfieren a "Cuando ya me empiece a quedar solo" en Sinfonía para Ana. Illa Carrillo Rodríguez ha destacado cómo las secuencias de canto en la cárcel de La noche... han impactado en la recepción de las canciones de Sui Generis:

Si bien el canto colectivo les permite a los detenidos crear un refugio utópico dentro del violento orden simbólico que constituye el centro clandestino de detención, la utopía que es construida por medio del canto y de los textos de Sui Generis tiene como único horizonte el pasado, ya que los protagonistas de La noche de los lápices saben que [...] nunca saldrán de la cárcel. En este contexto, tanto "Canción para mi muerte" como "Rasguña las piedras" se convierten en canciones autobiográficas que hablan de los sueños rotos de estos jóvenes y de su generación. Por medio de las secuencias en las que los adolescentes de La Plata cantan juntos las canciones de Sui Generis, la película La noche de los lápices transforma la música de dos hippies pacifistas (Charly García y Nito Mestre) - y de la subcultura a la que pertenecían entonces- en una crónica de la juventud que 'desapareció’ durante el Proceso de Reorganización Nacional, vinculando así el repertorio del "rock nacional" con la memoria colectiva de la generación setentista. (2008: II2-II3)

39 Lisa Di Cione (2015) cuestiona la idea de que el rock haya constituido realmente un movimiento de resistencia durante la dictadura militar argentina, señalando que, en todo caso, materializó la contracara dialéctica de la represión explícita. 
Pero si "Canción para mi muerte" y "Rasguña las piedras" cantan esperanzas que se revelaron après-coup utópicas ${ }^{40}$, las letras de "Cuando ya me empiece...", al contrario, que plantean un futuro no deseado, se cargan retrospectivamente de un sentido profético: la enumeración lírica de objetos inútiles anuncia un porvenir de soledad en una cultura materialista basada en éxitos superficiales, una soledad poblada de "fantasmas" (como el de Ana ${ }^{41}$. Esta soledad y este materialismo acechan a los que sobrevivirán a la dictadura (como Isa y Lito en el film), pero de modo más general pueden caracterizar los años posteriores a la esperanza de la "primavera alfonsinista". Al participar en la "sinfonía para Ana”, las voces de los cantantes se vuelven así vectores de una lucidez melancólica, que no se opone a la nostalgia que suscita la escucha de una canción de Sui Generis.

\section{DESEARÁS (CON) EL CANCIONERO MELÓDICO SETENTISTA}

El repertorio de canciones de Desearás... es más profuso y, si se quiere, complejo que el de la película dirigida por Ernesto Ardito y Virna Molina. Esto se debe fundamentalmente a que el relato se concentra en los vínculos sentimentales, afectivos y sexuales en el seno de la familia y, especialmente, de la tríada conformada entre las dos hermanas y la madre. Los hombres, duplicados al igual que las hermanas - los dos hermanos brasileños del pasado con quienes se relacionan amorosamente Ofelia y Lucía no tienen más importancia dramática que Andrés y Juan en el presente narrativo-cumplen funciones catalíticas antes que nodales en el armazón del conflicto y en el circuito de circulación de los deseos. Si tomamos las canciones en su conjunto, nuestra hipótesis es que estas brindan densidad y contenido sentimental a las pasiones amorosas que, en términos de acciones dramáticas llevadas adelante por los cuerpos de los personajes, se muestran como pulsiones sexuales. Dicho de otro modo, las canciones son la faceta reflexiva de unos deseos que tienden a expresarse explícitamente en las acciones de los personajes: los cunnilingus no tan oníricos de Juan a Ofelia, las diversas posturas sexuales en modalidad "lucha en el lodo" entre los mismos personajes, la embestida trasera de Juan a Lucía en el vaporoso cuarto de baño, la "cabalgata" de Ofelia a Andrés ante la mirada voyeur de

40 El estribillo de "Canción para mi muerte" reza: "Te encontraré una mañana / Dentro de mi habitación / Y prepararás la cama para dos"; "Rasguña las piedras" termina con una expresión de fe: "qué libres vamos a crecer".

4I La letra de la canción, en términos literales, remite a una artista, alla Norma Desmond, que en el ocaso de su vida es olvidada y repasa problemas dolorosos como la soledad, el vivir de la caridad de los demás y la presencia de la televisión como única compañía. En otras palabras, el tema aborda la reflexión de una artista que tuvo su momento de fama, y en la vejez, permanece sola con sus recuerdos. En el film, la canción de Sui Géneris es la que le brinda homogeneidad a los recuerdos y la que anticipa el desenlace: quedarse solo es la antesala de la desaparición debido a la compartimentación, al sentimiento de paranoia y a la ruptura de los lazos afectivos que se tendieron sobre los jóvenes estudiantes tras el golpe cívico-militar de 1976. 
Lucía. Por otra parte, si las canciones melódicas de los años sesenta y setenta generalmente fueron entendidas como el apotegma del amor romántico porque continuaban, de algún modo, una tradición de la canción popular urbana iniciada con el bolero y la balada, el modo en que Desearás... las hace operar en su puesta en escena parece sacar a la luz el revés violento y pulsional que embrionariamente ( $\mathrm{y}$ a veces de forma más expuesta) estas movilizan.

El espíritu de "cuerpo" o de corpus, en el que las partes son solidarias y se conectan entre sí, es notorio y sin duda forma parte del diseño estético de la película. Esto se justifica al menos por dos razones. En primer lugar, todas las canciones, con la única excepción de "Yo quiero a Lola" (Palito Ortega, I97I) ${ }^{42}$, son covers hechos específicamente para esta producción, bajo la dirección musical de Iván Wyszogrod. De este modo se percibe la intención de hacer dialogar y de construir una unidad conceptual y melódica entre la música incidental compuesta expresamente para Desearás... y las canciones preexistentes. En segundo lugar, el repertorio, con la única excepción de "These Boots Are Made For Walkin"', es homogéneo en cuanto a la elección de canciones populares que se masificaron en el primer lustro de la década de los setenta y que no se han convertido, creemos, en temas fuertemente connotados en el campo de la música melódica contemporánea. Para decirlo de otro modo, no se echa mano a las canciones más famosas de Palito Ortega, Sandro, Camilo Sesto, Raphael o, incluso, de Julio Iglesias, sino que se opta por melodías que no han sido actualizadas o reivindicadas por artistas pop contemporáneos.

En el entramado que hemos descripto, las letras anuncian o cristalizan los conflictos de la película. La balada "Tómame o déjame" (compuesta por Juan Carlos Calderón y popularizada por la banda Mocedades, I974), que Lucía canta en vivo, introduce los temas de la infidelidad y de la ruptura de una pareja en la misma fiesta de la boda; las letras de "Noche tú que sabes de todo" (Quique Villanueva, 1975), que se escucha en segundo plano (desde un vinilo) durante un desayuno entre las dos parejas, evocan los celos que se apoderan de Lucía al ver cómo Juan observa a su hermana. "Quédate aquí" (Quique Villanueva, I973), auricularizada desde el radio del coche, expone los deseos de Juan hacia Ofelia antes de que ambos comiencen su batalla sexual en el lodazal bajo la lluvia.

Otras canciones, en cambio, se usan como instancias de articulación, de mediación entre el presente y el pasado que revelan su continuidad, o más bien, exponen como el pasado sigue habitando el presente. Es el caso de "Agnese" (Nicola Di Bari, 1971), que empieza durante un flashback - escena en la piscina en la que Ofelia adolescente le explica

42 Se trata de un tema de corte festivo y paródico que enlaza a la perfección con el clima juguetón y picaresco que el film intenta instalar en la secuencia de créditos finales: el caballo y la grabación de Ofelia pierden cualquier sentido grave o dramático y se refuncionalizan, en sintonía con la voz de Palito, para narrar el inicio de un nuevo romance entre Andrés y Carmen. 
a Lucía, con demostración práctica incluida, cómo se da un beso de lengua- y en continuidad se visualiza un plano en ralentí de Ofelia adulta nadando en la misma piscina bajo la tutela visual de Andrés. Es el caso también de "La tarde que te amé" (Industria Nacional, 1972), que se inicia con el plano de un tocadiscos difícil de situar, pues se encuentra justo entre una escena del presente y una del pasado, la que expone el motivo traumático del conflicto entre las hermanas: la canción se oye en trasfondo cuando Ofelia le hace una felación al novio de su hermana a pedido de esta, lo cual desembocará en una tragedia (el suicidio del otro hermano); la letra sentimental de esa canción sugiere que el muchacho se enamora desesperadamente de Ofelia a raíz de su acto de sexo oral.

"Por el amor de una mujer" (Dany Daniel, popularizada por Julio Iglesias en su álbum A flor de piel de 1974) es la canción extradiegética que acompaña los créditos iniciales. La función de esta canción radica menos en los versos preciosistas de su lírica que en el tono y el tópico que la canción le imprime al relato. Julio Iglesias fue quizá la quintaesencia de lo más edulcorado y exacerbado de la canción melódica transnacionalizada de los setenta, un auténtico modelo sobre el cual muchos intérpretes latinos se montaron a la hora de construir un estilo propio. Sin embargo, el desarrollo de la letra instala los tópicos que desandará el film: ¿qué se es capaz de hacer por el amor de una mujer? $Y$ esta pregunta, en el contexto de la obra, no debe pensarse necesariamente enunciada por un hombre. La violencia que este amor no contenido provoca refiere no solo a la pasión que estas mujeres suscitan en los varones (actos suicidas de distinto orden), sino al que existe entre ellas: "Jugué con fuego sin saber / Que era yo quien me quemaba"; "Todo me parece como un sueño todavía / Pero sé que al fin podré olvidar un día / Hoy me siento triste pero pronto cantaré / Y prometo no acordarme nunca del ayer", "Mientras que ella se reía / Rompió en pedazos un cristal / Dejé mis venas desangrar / Pues no sabía lo que hacía”. Estos versos se asocian más a las vivencias entre Lucía y Ofelia que al vínculo entre hombres y mujeres. En un sentido clásico, la canción de créditos brinda claves de interpretación del tono y del conflicto que se presentarán en el relato.

"These Boots Are Made For Walkin" (interpretada por Nancy Sinatra, en su primer álbum Boots, I966) se despega del corpus anterior por diversas razones: no se trata de una balada romántica, no es de habla hispana y, además, está anclada en una fecha anterior a la representada en el film. El tema se inserta de forma diegética cuando Juan coloca un disco (una vez más, el tocadiscos), invita a bailar a Lucía y, ante su rechazo, Carmen incita a Ofelia para que haga las veces de partenaire. El desarrollo de la canción comprende dos partes diferenciadas: la escena en el interior de la casa y la salida de los hombres al exterior, para medir su hombría en una competencia de nado en mar abierto. En la primera parte, prevalece el montaje de dos series de planos: los que observan (Andrés, Lucía y Carmen) y los observados (los danzarines Ofelia y Juan). La cámara 
enlaza estas dos series a través de paneos en sentido circular, de izquierda a derecha, como gira un disco sobre una bandeja, o las agujas de un reloj. En la segunda parte, Juan y Andrés se convierten en protagonistas de la observación de las mujeres y los planos encajonados (estos subrayaban la extrema cercanía entre el techo, el piso y las paredes laterales) se transforman en tomas del mar y de una vista área de Carmen, Lucía y Ofelia mirando el espectáculo de la masculinidad acuática.
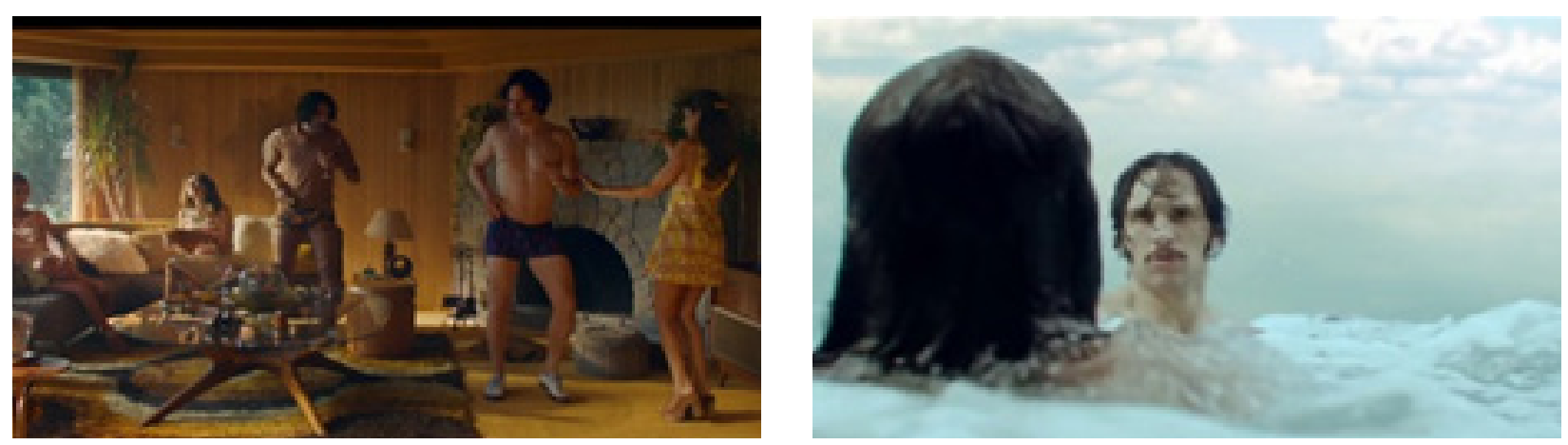

Figuras 23 y 24: Las dos partes de la secuencia dominada por la canción "These Boots Are Made For Walkin”" en Desearás...

La letra de la canción, quizá como ninguna de las otras, explota las tensiones en diversos sentidos en relación con la trama, ya desatadas y sin retorno, entre los personajes. En primer lugar, la voz cantante expresa conocer de la infidelidad y del engaño de su pareja, con quien confronta por sus aventuras y su desamor. Este tramo se identifica inmediatamente con Lucía, quien durante la escena del baile y con la inestimable ayuda de su madre, parece haber confirmado todo lo que temía, pero también podría vincularse con Andrés, quien se percata de lo mismo y reacciona con vehemencia a las provocaciones de Juan ${ }^{43}$. El estribillo configura una enunciadora empoderada, decidida a la acción, tanto a la de tomarse venganza como a la de continuar camino sola: "Well, these boots are made for walking, and that's just what they'll do / One of these days these boots are gonna walk all over you". El montaje, con nula ingenuidad, hace coincidir el momento en el que los dos hombres se introducen en el mar con la frase: "One of these days these boots are gonna walk all over you". Se ha declarado la guerra ${ }^{44}$, las pujas entre egos, las tensiones entre deseos encontrados se intensificarán con mayor velocidad a partir de esta secuencia (ubicada en el justo medio del relato). Los aspectos rítmicos e instrumentales son solidarios con el análisis precedente: el estilo country-pop propone una estructura

43 Juan dirigiéndose a Andrés: “¿Estás para nadar mar adentro? Tu mujer me hizo entrar en calor. ¿Necesitás chaleco salvavidas? ¿O que venga Pelé en su lancha a rescatarte?”.

44 En un ensayo sobre cine y cultura popular no podemos dejar de señalar que la connotación bélica, explícita a nivel de género (gender) en la letra de la canción, se literaliza en guerra convencional, guerra entre hombres, con el uso que de ella hace Stanley Kubrick en Full Metal Jacket (1987). 
rítmica uniforme y bien demarcada por la pandereta, el bajo eléctrico, y el cross-stick (golpe de aro) sobre el redoblante. El rasgueo de guitarra acústica enfatiza el concepto rítmico y, junto con la guitarra eléctrica y los vientos, se marcan las cadencias armónicas y el crescendo de la canción hacia el estribillo. Puesto que la contienda, en el baile y en el bar y en el intercambio de miradas, es la clave que organiza esta secuencia, la canción que popularizaría Nancy Sinatra no solo apuntala estas fricciones sino que nos recuerda que el vector que circunscribe el desarrollo del conflicto es el deseo de las mujeres ${ }^{45}$.

\section{A TU LADO RETROCEDE EL TIEMPO}

"Rubí" (Babasónicos, 200I) constituye un caso particular como engranaje melódico y sonoro de Desearás al hombre de tu hermana. La canción es, a todas luces, un anacronismo, si consideramos el verosímil del pasado representado (la primera mitad de la década de los setenta). No obstante, si ampliamos un poco la visión y la escucha, no es difícil trazar puentes entre este supuesto anacronismo y el resto del repertorio o corpus de canciones que componen el entramado musical y narrativo del film. Babasónicos es una banda de pop-rock cuyos músicos nacieron en los primeros setenta. Entre las influencias que atraviesan su discografía aparecen el retro, el glam y el pop de los años setenta, sobre todo en dos de sus álbumes: Jessico (200I, del que "Rubí" es la pista Io) e Infame (2003). Además, tanto la lírica de algunos de los temas (enunciaciones en género femenino) como el look de la banda recuperan la visualidad y los tópicos de aquel periodo. En el marco de la diégesis, "Rubí" es presentada como la última composición de Lucía y es interpretada por ella misma, quien se supone es una cantante famosa y en ascenso. Se trata de un tema melódico, con cierta cadencia asimilable al bolero, en el cual el enunciador, portador de un discurso amoroso, expresa el deseo irrefrenable que le produce una mujer en tanto talismán que hace "retroceder el tiempo". Si quisiéramos asignar la letra a un personaje de la trama, nuestro rubí, sin dudas, sería Ofelia:

Imposible /Olvidar tu talismán / Irresistible / Remar contra tu atracción / A tu lado retrocede el tiempo / Cualquier día es el mejor momento / Increíble / Tentación es el amor / Tu aliento carmesí / Tu flor de lis / Junto a mi boca / Fumar de tu rubí / Quererte así / Beberte a gotas.

Las descripciones de esta letra remiten claramente a Ofelia; algunas de ellas se corresponden incluso con frases pronunciadas por Juan. Esta idea se refuerza si pensamos que

45 Las/los lectoras/es de este ensayo no tendrán dudas en esta instancia que la película (también, creemos, Sinfonía para Ana) brinda sobrados materiales para un análisis desde una perspectiva de género. No es la orientación que pretende tomar este artículo, no obstante recomendamos el texto ya citado de Arévalos y Montes (20I8) quienes sí se internan en un estudio atento a algunos de estos elementos. 
"Rubí" es interpretada dos veces. La primera vez, Lucía canta con el acompañamiento de guitarra criolla de Andrés, alegres ambos, mientras Juan y Ofelia se hallan envueltos en el frenesí del barro y la lluvia. La segunda vez, con Andrés de camino al hospital, Lucía y Juan (con el rostro sangrante y deformado) interpretan una vez más la canción. Mientras tanto, Ofelia, tendida sobre la alfombra, llora. En realidad, todos lloran.
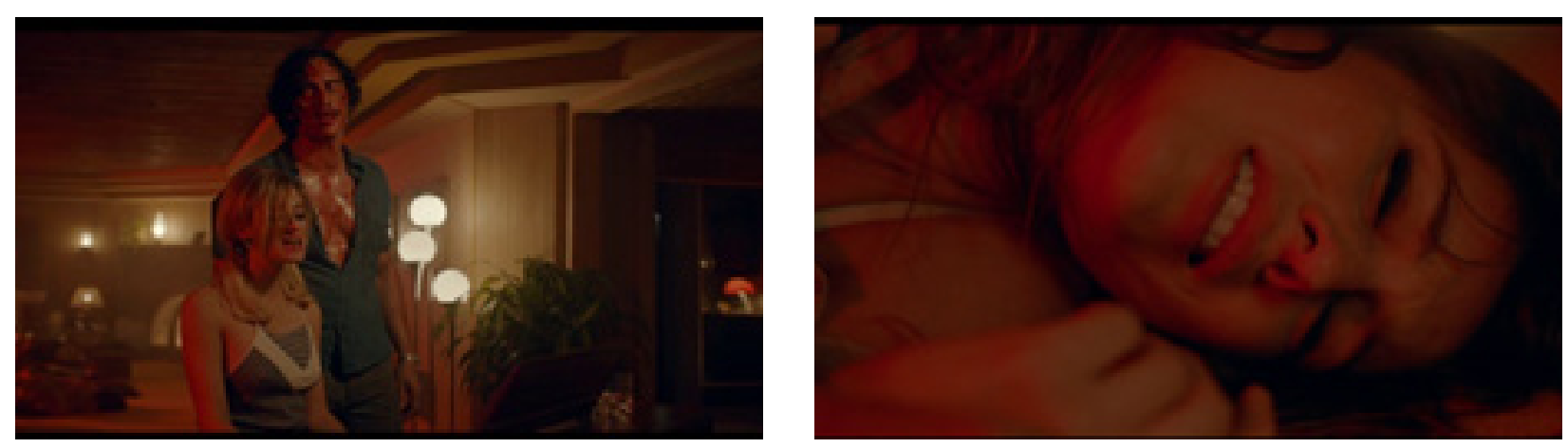

Figuras 25 y 26: la segunda vez que Lucía canta "Rubí"; todos lloran (Desearás...)

Esta canción debe leerse en serie con “Tómame o déjame” (también interpretada por Lucía) porque las dos se ubican en el inicio (fiesta de boda) y en la clausura del film (aparente ruptura de la pareja y traición consumada). Al parecer, Juan "tomó" la decisión de "dejar" a Lucía, aunque esa situación no termina de resolverse. La actriz Mónica Antonópulos, quien encarna a Lucía, realiza, en términos de Claudia Gorbman (20II), una escena de "artless signing", puesto que su performance no es la de una intérprete profesional y los versos que emite tienen una relación específica con la trama porque expresan aquello que no puede decir de otro modo: la desconfianza, la pasión y el deseo por su hermana. En palabras de Gorbman (20II), en este tipo de escenas, muchas veces, se interpreta una canción en cuya letra se manifiesta una verdad más profunda de la que el emisor conoce sobre sí mismo. "Rubí" es entonces la demostración más auténtica de una subjetividad (la de Lucía) y la de una atracción que se inició en la infancia, impronunciable en el discurso oral, pero que la canción -y especialmente, una canción anacrónica que reconoce "a tu lado retrocede el tiempo"- permite expulsar: existe algo del orden del monólogo, de lo que se dice para uno mismo, de una intimidad reacia a revelarse ante los demás que surge, como una erupción, en estas escenas de "artless signing".

\section{CONCLUSIÓN}

Sinfonía para Ana y Desearás al hombre de tu hermana son dos films que evocan la década de los setenta desde una perspectiva centrada en la memoria afectiva y cultural. Parafraseando una vez más a Babasónicos, cuando las observamos, retrocede el tiempo. Esta vuelta atrás en el tiempo acarrea cierta nostalgia que es bastante paradójica, ya que las 
utopías de revolución política y de liberación sexual que se proyectan en los primeros años setenta no son disociables de una explosión intensa de violencia. Para apelar a esas luchas en el presente, y para hacer sentir las tensiones entre mitificación nostálgica y conciencia de la violencia, las películas recurren a un tejido de referencias cinematográficas (que las sitúan aparentemente en dos continentes aparte), sin duda, pero recurren también y más fundamentalmente al dispositivo de la voz grabada y al papel de las canciones diegéticas.

Sinfonía para Ana alimenta el mito de una época perdida a partir de otro mito, el de las tecnologías analógicas cuya aura se ha perdido con el auge de lo digital. Jugando con las palabras: si Sinfonía... auratiza las luchas de los setenta desde el sonido y, también, desde la inserción de imágenes rodadas en super-8 que responden al dispositivo vocal-sonoro instaurado como base narrativa, Desearás... oraliza esas luchas, en el sentido a la vez literal y sexual del término; vincula la voz grabada y las canciones sentimentales al sexo oral, y las erige en instancias afectivas que nos permiten sentir la violencia de los deseos que se destaparon en esta época.

De la violencia y de los deseos que circulan en los films también da cuenta la puesta en escena de las miradas, esta siendo un componente fundamental en la organización espacial del cuadro y en las estrategias de montaje. Mientras Desearás... parece dar cuenta de una época en la que el ejercicio de la intimidad (el mismo que encarna el diario grabado de Ofelia) resulta imposible - la vigilancia de los personajes se ejerce desde diversas posiciones de control del espacio que les permite el emplazamiento de la casa-, Sinfonía para Ana muestra miradas perdidas de los personajes que no tienen un contraplano o un objeto al que estén dirigidas. Ana y el rector Aragón monopolizan los planos de estas características. En esta obra las relaciones íntimas entre los jóvenes son interrumpidas por la violencia estatal, lo que justifica el vaciamiento de deseo, la proyección melancólica de la pérdida, y el desasosiego que se percibe en las miradas de estos personajes. Hemos analizado cómo esta interrupción se cristaliza en la canción de Sui Generis "Cuando ya me empiece a quedar solo" y en la secuencia con la que se articula.

Volviendo desde ahí al eje central de nuestra comparación impertinente: el viaje temporal al que nos invitan las películas tiene en común una narrativa que utiliza como polea de transmisión artefactos analógicos de registro de la voz. Creemos que este elemento no es aleatorio ni ingenuo: los films son conscientes de que ya no es posible volver a la década de los setenta a partir de narrativas testimoniales, de relatos costumbristas, o de fábulas arraigadas en un discurso político espetado a la audiencia. O tal vez, sí, es posible, pero resulta menos efectivo para producir lazos de identificación que reafectivicen la relación de los públicos con un pasado que no deja de producir efectos políticos sobre el presente y con el cual, en términos culturales (la estructura familiar es el huevo de la 
serpiente), existen más continuidades que rupturas. Es por esto que la violencia, expresada a través de diversas estrategias de puesta en escena en las dos películas, reverbera sobre estos discursos audiovisuales de maneras que quizá son más audibles que visibles. Tal vez, parafraseando ahora los primeros diálogos de una antigua película, hemos visto mucho de los setenta pero, en los films, hemos oído muy poco de lo que estos tienen para transmitirnos. 


\section{BIBLIOGRAFÍA}

Aguilar, Gonzalo (2006). Otros mundos. Un ensayo sobre el nuevo cine argentino. Buenos Aires: Santiago Arcos.

Amado, Ana (2009). La imagen justa. Cine argentino y política (I980-2007). Buenos Aires: Colihue. Anad, Guillermo. “La nueva guarida del tango (Tango's New Lair)”. Journal of Multidisciplinary International Studies 5, I (2008).

Arévalos, Valeria y Montes, Viviana. "Circulación del deseo femenino y sexploitaition-camp en Desearás el hombre de tu hermana de Diego Kaplan”. Argus-a 7, 28 (2018).

Barthes, Roland (I986). "El 'grano' de la voz”. Lo obvio y lo obtuso: imágenes, gestos, voces. Barcelona: Paidós: 262-27I.

Bazin, André (2004). ¿Qué es el cine? Madrid: Rialp.

Bijsterveld, Karin, y Van Dijck, José (2009). Sound Souvenirs - Audio Technologies, Memory and Cultural Practices. Amsterdam: Amsterdam University Press.

Bilik, Julieta (20I6). "Entrevista a Virna Molina y Ernesto Ardito". Directores II (2016): 74-77.

Bolter, Jay David, y Grusin, Richard (I999). Remediation. Understanding New Media. Cambridge MA-Londres: The MIT Press.

Brienza, Lucía. "Los usos del pasado dictatorial en los primeros años de democracia. Argentina, I983-1989". Revista Escuela de Historia 9, 2 (2010).

Caimari, Lila. "Infinito particular: lo cultural como archivo". Prismas. Revista de historia intelectual II (2007): 2I3-2I8.

Campo, Javier. "¿Cine + sociedad? El caso del documental político entre las narrativas revolucionarias y las democrático humanitarias". Tempo e Argumento I0, 23 (2018): 337-357.

Carassai, Sebastián (2013). Los años setenta de la gente común. La naturalización de la violencia. Buenos Aires: Siglo XXI Editores.

Carrillo Rodríguez, Illa (2008). "Los ecos de la memoria: el 'rock nacional' argentino como elemento cinematográfico". Vargas, Herom; Glaucia, Silva y Ruiz, Agustín (eds.). Actas del VIII Congreso de la IASPM-AL. Lima: Ioo-I2I.

Catelli, Nora (2007). En la era de la intimidad. Rosario: Beatriz Viterbo Editora.

Chion, Michel (1982). La voix au cinéma. Paris: éditions de l'Étoile/Cahiers du Cinéma.

Chion, Michel (2018). La audiovisión. Buenos Aires: La Marca Editora.

Cosse, Isabella; Felitti, Karina y Manzano, Valeria (eds.) (2010). Los '6o de otra manera. Vida cotidiana, género y sexualidades en la Argentina. Buenos Aires: Prometeo.

Di Cione, Lisa. "Rock y dictadura en la Argentina: reflexiones sobre una relación contradictoria”. Afuera. Estudios de crítica cultural X, I5 (2015).

Fanjul, Adrián Pablo (2014). "Life Trajectories and Dejuvenilization in Argentine Rock". Vila, Pablo (ed.). Music and Youth Culture in Latin America. New York: Oxford University Press: 26I-283. Felitti, Karina (2012). La revolución de la píldora. Buenos Aires: Edhasa. 
Franco, Marina, y Lvovich, Daniel. "Historia Reciente. Apuntes sobre un campo de investigación en expansión". Boletín del Instituto de Historia Argentina y Americana "Dr. Emilio Ravignani" 47 (2017): 190-2I7.

Gilman, Claudia (2003). Entre la pluma y el fusil: debates y dilemas del escritor revolucionario en América Latina. Buenos Aires: Siglo XXI Editores.

Gorbman, Claudia. "Artless Singing”. Music, Song and Moving Image 5, 2 (201I): I57-I7I.

Guillén, Marco. "Desearás al hombre de tu hermana: Entrevista con el director Diego Kaplan”. Cuatro Bastardos (2017).

Hilb, Claudia (2018). ¿Por qué no pasan los 70? No hay verdades sencillas para pasados complejos. Buenos Aires: Siglo XXI Editores.

Lo Russo, María Belén y Lo Russo María Florencia (2018). “Sinfonía para Ana: un relato íntimo de la militancia juvenil en los años setenta”. Actas del XI Seminario Internacional Políticas de la Memoria "Memorias subalternas, memorias rebeldes". Buenos Aires: Centro Cultural de la Memoria Haroldo Conti.

Lusnich, Ana Laura (I994). "El Instituto Nacional de Cinematografía”. España, Claudio (comp.). Cine argentino en democracia (1983-1993). Buenos Aires: Fondo Nacional de las Artes:303-306.

Mourlet, Michel. "Sur un art ignoré". Cahiers du cinéma 98 (I959): 23-37.

Ortiz, Mónica. "Entrevista al director y a la guionista de Desearás al hombre de tu hermana". Cinéfilo Serial (16/Io/20I7). [Entrevista audiovisual transcripta por los autores del artículo].

Quílez Esteve, Laia (2008). “Sutiles pretéritos”. Martín Gutiérrez, Gregorio (ed.). Cineastas frente al espejo. Madrid: T\&B - Festival Internacional de Cine de las Palmas: 83-Ioo.

Piedras, Pablo (20I4). El cine documental en primera persona. Buenos Aires: Paidós.

Powrie, Phil (20I7). Music in Contemporary French Cinema. The Crystal-Song. Londres: Palgrave Macmillan.

Romero, Luis Alberto (2006). "La política en los barrios y en el centro: parroquias, bibliotecas populares y politización antes del peronismo”. Korn, Francis y Romero, Luis Alberto (comps.). Buenos Aires/Entreguerras. La callada transformación, I9I4-I945. Buenos Aires: Alianza: 33-58.

Russo, Juan Pablo. "Ni santas ni putas. Crítica de Desearás al hombre de tu hermana”. Escribiendocine.com (02/10/2017).

Schrey, Dominik (2014). "Analogue Nostalgia and the Aesthetics of Digital Remediation". Niemeyer, Katarina (ed.). Media and Nostalgia: Yearning for the Past, Present and Future. Basingstoke: Palgrave Macmillan: 27-38.

Sterne, Jonathan. "The Death and Life of Digital Audio". Interdisciplinary Science Reviews 3I, 4 (2006): 338-348.

Van der Heijden, Tim. "Technostalgia of the Present: from Technologies of Memory to a Memory of Technologies”. NECSUS. European Journal of Media Studies 4, 2 (2015): I03-I2I. 
Zimerman, Gaspar. "Desearás al hombre de tu hermana: Melodramón erótico con toques de comedia". Clarín.com (04/10/2017).

Zimmermann, Patricia (I995). Reel Families. A Social History of Amateur Film. Bloomington: Indiana University Press. 